\title{
Um Encontro às Escuras: Processo Criativo
}

Estou perigosamente achando que sou capaz de tudo.

(Denise Stoklos)

Chega de adiar. A hora de começar o processo criativo havia che-
gado. Era o momento de enfrentar a solidão da sala de ensaio. Era o tempo do esperado encontro com esse eu que aspirava à ideia de ator-autor. Depois de tanta "preparação", encontrava-me na ansiosa situação do blind date. Os pressupostos teóricos e os materiais que no momento me serviram de preparação tinham me "arrumado" para o esperado encontro com o desconhecido. Mas, como acontece nesse tipo de situações, na hora, parecia-me que não tinha escolhido as roupas adequadas e que poderia ter dedicado mais tempo no meu apresto. Tratava-se de uma situação desconfortável, cheia de silêncios e movimentos desajustados. Foi um encontro longo e difícil. O desconhecido acabou sendo tão silencioso e inexpressivo quanto eu. Saí da sala de ensaio com uma sensação de frustração que só encontrou consolo na esperança de um segundo encontro mais frutífero.

Como ator-intérprete, estava acostumado a chegar ao primeiro ensaio com uma preparação mais concreta, embora menos prolífera. Pelo menos, já tinha lido o texto e já havia escutado o conceito de encenação que o diretor projetava realizar. Alguma cena estudada e alguma proposta de ação cênica já tinham passado pela minha mente quando chegava aos primeiros ensaios. Mas, realmente, na nova situação que enfrentava, chegava como aquele indivíduo que não tem 
como se preparar para um encontro às cegas marcado por um amigo bem-intencionado. Eu só chegara com a confiança de que era possível fazer aquilo que vários colegas consideravam um despropósito, algumas leituras e umas imagens que me motivavam a falar de coisas que me interessavam. Não sabia como proceder. A única coisa que achava que podia fazer naquele momento era partir dessas imagens para tentar iniciar isso que não tinha forma. De fato, assim começou a fluir aquilo que depois encontrou um sentido próprio. No entanto, antes de começar, tive que experimentar o que não devia fazer.

\section{Partindo (saindo) do conhecido}

Como assinalei acima, o primeiro encontro com a sala de ensaio não foi muito proveitoso, pelo menos no sentido de começar a dar forma ao espetáculo unipessoal que estava me propondo fazer. Realmente, estava na hora de começar a "fazer”. Fazer o quê? Passou algum tempo antes que essa resposta chegasse. Mas, pelo menos, eu já sabia o que não faria. A proposta de $\mathrm{O}$ ator em solidão tinha como propósito quebrar com a prática que me colocou por muito tempo como ator-intérprete. Isso demandava repensar meu fazer. $\mathrm{O}$ fazer do intérprete era bem conhecido e tinha uma sequência de passos que eu identificava mais ou menos com clareza: leitura do texto dramatúrgico, reconhecimento do conceito de encenação, improvisações a partir das propostas do diretor e dos outros atores, marcação de cenas etc. Mas o fazer do artista não tinha uns passos predeterminados que eu pudesse seguir. Como definir, então, esse "fazer" ? Luigi Pareyson (1993) me deu algumas luzes para entender o que isso significa. Para ele, na arte, o fazer realmente é um "formar".

Na prática do ofício que eu conhecia, o imperativo do ator está no fazer. De fato, a ação física, como ferramenta de trabalho, sustenta as bases das propostas dos atores. Muitas vezes, escutei do diretor a seguinte frase: “[n]ão pense, faça". Esse imperativo permanecia nas minhas primeiras improvisações; entendia-o como um convite a não intelectualizar minha criação. Continuo acreditando na importância dessa frase precisamente porque a arte não existe no mundo das ideias 
e das abstrações, mas é uma experiência que materializa aquilo que talvez teve sua origem no universo do intelecto ou do afeto. $\mathrm{O}$ que me revelou essa frase não era o que eu precisava deixar de fazer, mas sim que devia transformar esse fazer.

É preciso, sobretudo, recordar que o "fazer" é verdadeiramente um "formar" somente quando não se limita a executar algo já idealizado ou realizar um projeto já estabelecido ou a aplicar uma técnica já predisposta ou a submeter-se a regras já fixadas, mas no próprio curso da operação inventa o modus operandi, e define a regra da obra enquanto a realiza, e concebe executando, e projeta no próprio ato que realiza. (Pareyson, 1993, p. 59)

A citação anterior me ajudou a entender que, quando o diretor me pedia para fazer e não para pensar, estava me dizendo que eu não tinha que me inquietar pela forma, já que essa preocupação era seu trabalho e não o meu. Agora, quando a forma era minha responsabilidade, descobri que meu fazer tinha, sim, que contemplar a formação da obra de arte. Primeiro esclarecimento: a forma não deveria ser objeto de ocupação do fazer do ator-intérprete, porém, do ator-artista, sim.

Essa clareza não apareceu no início da pesquisa —o leitor pode corroborar que não faz parte dos pressupostos—, mas partiu da ideia, ainda abstrata, de vislumbrar a possibilidade de um ator-autor —o que faz, sim, parte dos pressupostos- A primeira ideia que eu tinha da criação do espetáculo unipessoal no contexto desta pesquisa seguia a tradição de uma prática que considera o dramaturgo autor do espetáculo teatral, já que demandava a escrita de um texto como passo inicial e "necessário" para o sucesso do projeto.

Assim, a proposta inicial abrangia as seguintes etapas: 1) escrita de um texto dramatúrgico que contemplasse a obra de André Gide e as referências pictóricas e autobiográficas para a criação de uma ficção que pudesse ser representada no palco; 2) concepção do espaço cênico, sonoplastia e figurino; 3 ) memorização do texto e montagem de cenas a partir de improvisações baseadas nele (etapa que seria filmada o tempo todo); 4) observação do material registrado para seleção das propostas mais "relevantes" e 5) marcação final. 
Esse planejamento "natural" do processo criativo estava relacionado com o que eu conhecia como ator-intérprete. De fato, conservava as etapas habituais de minha experiência profissional. A única coisa que o diferenciava dessa experiência era a particularidade de que eu seria dramaturgo, ator e encenador do meu próprio espetáculo. Passou algum tempo antes de eu perceber que esse caminho não me conduzia à ideia de ator-autor que procurava. Simplesmente, afirmava aquela tradição da qual pretendia me desprender. Meu trabalho como ator continuaria sendo o de intérprete, só que as palavras usadas não seriam de autoria de outra pessoa. Finalmente, continuaria afirmando que o autor no teatro é o dono da palavra. Além disso, meu fazer como ator continuaria estando submetido às regras fixadas pela prática interpretativa. Entendi, então, que essa rota não transformaria meu fazer em um formar.

Formar, portanto, significa "fazer", mas um fazer tal que, ao fazer, ao mesmo tempo inventa o modo de fazer. Trata-se de fazer, sem que o modo de fazer esteja de antemão determinado e imposto, de modo que bastaria aplicá-lo para fazer bem: é mister encontrálo fazendo, e só fazendo se pode chegar a descobri-lo. (Pareyson, 1993 , p. 59, itálico no original)

Assumir a saída do ato interpretativo para me converter realmente em um ator que seria autor do seu próprio espetáculo exigia tomar uma decisão difícil: desprender-me dos procedimentos conhecidos e encontrar o meu próprio fazer. $\mathrm{O}$ tempo da emancipação real tinha chegado.

Entender o processo criativo do espetáculo unipessoal no contexto desta pesquisa como busca da forma também contribuiu para compreender que, no estágio do ofício (ator-intérprete), o ator tem que se perguntar como traduzir em ação cênica as propostas do encenador ou do dramaturgo. Não é por acaso que, quando se fala da "arte do ator", se esteja falando dela precisamente no sentido de ofício, das técnicas e dos procedimentos dos quais se vale o ator para seu fazer no palco. Enfim, arte entendida como maneira, modo. No estágio do ator-artista, e tendo nesse âmbito o imperativo da formatividade da obra, a arte do ator não se pode limitar à maneira, mas desdobrar ao 
dizer ${ }^{1}$. Segundo esclarecimento: a pergunta principal desta pesquisa não é mais sobre o como, é sobre o quê. Nesse sentido, este capítulo se ocupa de como se chegou a "o quê" e pretende descrever o percurso que definiu um novo fazer.

Uma das características mais particularidades do novo fazer desta pesquisa é a ideia da unipessoalidade da criação, ou seja, de um exercício cênico que pretende quebrar com uma prática sustentada na coletividade. As cinco etapas inicialmente contempladas para a criação do espetáculo ignoravam essa ideia e consideravam que a unipessoalidade já era obviedade em se tratando de um exercício projetado e executado por uma pessoa só. Mas, simplesmente, estavam "individualizando" uma série de procedimentos que parece estar mais de acordo com uma experiência prevista para a participação de vários indivíduos. Terceiro esclarecimento: passar da experiência coletiva do fazer cênico à prática unipessoal demanda uma mudança de procedimentos que só pode responder às características da individualidade que se pretende defender. Era óbvio, então, que não se tratava de assumir o processo criativo a partir das fórmulas já conhecidas. Partir-sair do conhecido representou entender o que Pareyson (1993) expressa de maneira sintética no seguinte depoimento:

[...] formar significa por um lado fazer, executar, levar a termo, produzir, realizar e, por outro lado, encontrar o modo de fazer, inventar, descobrir, figurar, saber fazer; de tal maneira que invenção e produção caminham passo a passo, e só no operar se encontrem as regras da realização, e a execução seja a aplicação da regra no ato próprio que é sua descoberta. (p. 60)

De acordo com Pareyson, então, o primeiro erro, caso eu tivesse assumido a criação com as etapas do projeto inicial, teria sido não reconhecer precisamente o caráter individual da experiência criativa que estava enfrentando porque, como ele mesmo (1993) assinala, "[s]e a obra a

1 Vale a pena aqui lembrar as palavras, já apresentadas no primeiro capítulo, de Pareyson (1997): “[o] fazer que não seja ao mesmo tempo um dizer não atinge a arte, mas permanece confinado no ofício" (p. 64). 
fazer é sempre individual, determinada, circunstanciada, o modo de fazê-la deve sempre, e cada vez de novo, ser inventado e descoberto" (p. 60). Tratava-se, pois, não só de inventar o espetáculo, mas também de inventar o modo de fazê-lo.

\section{À procura de um novo fazer}

O processo criativo que estava começando a desenvolver me confrontou com uma nova maneira de entender o meu fazer. Partindo do reconhecimento das diferenças entre o que seria o novo (o fazer artístico) e o antigo (o fazer do intérprete) na minha experiência profissional, enfrentava-me com uma busca que não parecia ter um ponto de partida determinado. Continuando com Pareyson (1993), já era claro que, “[...] na arte propriamente dita, a formatividade, não sendo subordinada aos objetivos de nenhuma operação específica, se reja unicamente por si, sem ter que apelar a um critério extrínseco nem esperar sanção de uma lei que lhe seja imposta" (p. 65).

Teria, então, que definir as regras da obra que pretendia criar. Como fazer aquilo sem considerar critérios extrínsecos? Diz Pareyson (1993) que, "[n]a arte, quando se trata da obra, tudo tem que ser inventado e, sobretudo, aquilo que institui a sua regra como tal, i. é, a adequação da obra consigo mesma" (p. 67). Mas como inventar a priori uma regra que se adapte à obra se ela nem tem forma ainda? Obviamente, pensar que isso poderia ser produto da antecipação era ingenuidade porque "[n]a arte não existe outra lei geral a não ser a mesma regra individual da obra que deve ser inventada no decorrer da operação" (Pareyson, 1993, p. 66).

Entrar na sala de ensaio representava, assim, um paradoxo. Tratava-se de começar a dar forma àquilo que não se sabia nem como tinha que ser feito. Eis por que se define aqui o processo criativo no contexto desta pesquisa como um encontro às escuras. Existia, claro, uma série de imagens, de projeções do que seria o espetáculo, uma ideia de projeto, materiais de trabalho, mas ainda não havia a ponte entre isso que antecedia a criação da obra e a obra como resultado. 
O que eu devia definir era os meios que fariam possível a execução dessas ideias.

Segundo Pareyson (1993), “[...] a execução deve ser um prolongamento da própria concepção do projeto, não só no sentido de lhe ter que interpretar a capacidade operativa, mas pode até chegar a condicioná-la, modificando a ideia no decorrer da execução" (p. 64). Foi o que aconteceu com o espetáculo unipessoal fruto desta pesquisa. $\mathrm{O}$ encontro às escuras acabou trazendo à tona um espetáculo que, embora conservasse a essência do projeto, atingiu uma aparência que pouco se relacionava com as primeiras imagens que o concebiam. Ainda que essa última afirmação pareça uma obviedade para quem faz arte, dado que se trata de uma característica própria da natureza do processo criativo, revela várias diferenças entre o que representava meu papel como ator-intérprete em um espetáculo qualquer e o que foi ser o criador único e responsável de toda a encenação. Mas não será falado disso agora. Antes, vamos ver como se enfrentou essa fase de execução que conduziu à forma final do espetáculo unipessoal.

\section{Um fazer cartográfico}

Uma das tantas luzes que me deu a leitura de Luigi Pareyson foi a de que a formação da obra de arte sempre tem algo de aventura. Parece-me que a metáfora da aventura e a do encontro às escuras estão intimamente relacionadas, sobretudo, no sentido de empreender uma espécie de viagem sem destino concreto e sem mais certezas do que as dadas pela mesma experiência à medida que ela vai se desenvolvendo:

[...] a operação artística é um procedimento em que se faz e atua sem saber de antemão de modo preciso o que se deve fazer e como fazer, mas se vai descobrindo e inventando aos poucos no decorrer mesmo da operação, e só depois que esta terminou é que se vê claramente que aquilo que se fez era precisamente o que se tinha a fazer e que o modo empregado em fazê-lo era o único em que se poderia fazê-lo. (Pareyson, 1993, p. 69) 
Sendo a produção artística uma aventura, Pareyson (1993) fala do artista como um jogador que tenta a sorte: "sua execução é ao mesmo tempo procurar e encontrar, tentar e realizar, experimentar e efetuar. Ele deve fazer a obra, e somente depois da obra acabada é que ele poderá dizer se ele encontrou a forma" (p. 69, itálico no original). Essa maneira de assumir o processo criativo tinha tudo a ver com o que estava experimentando no início do meu. As palavras de Pareyson me convidavam a "me jogar" em uma experiência sem regras a priori, na qual mergulharia por vários meses.

Uma ideia parecida pode ser percebida na experiência cartográfica. Como pesquisa, “[a] cartografia é um método [...] que visa acompanhar um processo, e não representar um objeto" (Passos, Kastrup e Escóssia, 2012, p. 32). Entendendo o processo criativo do espetáculo unipessoal também como pesquisa acadêmica, o método da cartografia não só me ajuda a legitimar uma escolha que privilegia a participação de um processo em lugar da observação de uma obra artística para estudar os alcances desse tipo de espetáculos, mas também se constitui como ferramenta metodológica na busca desse novo fazer como ator.

Nesse sentido, os livros Pistas do método da cartografia (Passos, Kastrup e Escóssia, 2012) e Cartografia sentimental (Rolnik, 2006) foram fundamentais para entender como era que operava meu fazer neste processo de pesquisa/criação, já que o sentido da cartografia se encontra no acompanhamento de percursos, na implicação em processos de produção, na conexão de redes ou rizomas, no desenvolvimento de práticas de acompanhamento de processos inventivos e de produção de subjetividades (Passos, Kastrup e Escóssia, 2012).

Não é por acaso, nesse sentido, que aventura seja uma palavra que os estudiosos da cartografia também usam para falar da experiência em pesquisas desse tipo. Eduardo Passos, Virgínia Kastrup e Liliana da Escóssia (2012) assim o expressam quando tratam da formação do cartógrafo e do problema das políticas cognitivas:

[...] o corpo a corpo com o campo de pesquisa comporta sempre uma dose de imprevisibilidade e mesmo de aventura. Habitar um território de pesquisa não é apenas buscar soluções para problemas prévios, mas envolve disponibilidade e abertura para o encontro 
com o inesperado, o que significa alterar prioridades e eventualmente redesenhar o próprio problema. (p. 204)

Esse tipo de afirmações constitui a matéria-prima que me levou a estabelecer essas relações entre o fazer da criação artística e o da pesquisa cartográfica. Outra evidência disso aparece, por exemplo, quando Suely Rolnik fala do modo de proceder do cartógrafo, o que a aproxima bastante do modo de proceder que Pareyson outorga ao artista. O cartógrafo age de maneira homóloga à do artista quando precisa inventar seu fazer sem atingir regras extrínsecas. "Restaria saber quais são os procedimentos do cartógrafo. Ora, estes tampouco importam, pois ele sabe que deve 'inventá-los' em função daquilo que pede o contexto em que se encontra. Por isso ele não segue nenhuma espécie de protocolo normalizado" (Rolnik, 2006, p. 66, itálico no original).

O processo de dar forma ao espetáculo unipessoal se alimentou da invenção dos seus próprios procedimentos e partiu da compreensão de que as normas pré-desenhadas para o trabalho do ator atingem o campo do ofício, e não o da criação artística. No sentido de pesquisa, a cartografia se localiza muito mais perto da criação do que da revelação de sentidos, motivo pelo qual seu aproveitamento se torna ainda mais pertinente no contexto desta pesquisa.

\begin{abstract}
"Cartógrafo", quando queremos enfatizar que ele não "revela" sentidos (o mapa da mina), mas os "cria”, já que não está dissociado de seu corpo vibrátil: pelo contrário, é através desse corpo, associado ao uso molar de seus olhos, que procura captar o estado das coisas, seu clima, e para eles criar sentido. (Rolnik, 2006, p. 71)
\end{abstract}

Isso dá à cartografia um caráter estético, o que justifica ainda mais sua presença nesse tipo de pesquisas. Para Passos, Kastrup e Escóssia (2012), a experiência da pesquisa cartográfica assume uma dimensão estética, precisamente, porque diz respeito aos processos de criação de realidade. Além disso, os pesquisadores assinalam que: "[p]roduzir conhecimento e produzir realidade se tornam face e contraface da experiência cognitiva, $o$ que impõe a complexidade ético-estético-política da ação do pesquisador" (Passos, Kastrup e Escóssia, 2012, p. 203). Tudo isso se consegue a 
partir de uma sensibilidade desenvolvida pelo pesquisador - nesse caso, também, criador-, que se envolve no processo sem gerar distâncias entre seu corpo e o objeto do qual se aproxima, chegando à cognição inventiva não por adesão teórica, mas sim por "práticas cognitivas efetivas e encarnadas” (Passos, Kastrup e Escóssia, 2012, p. 203).

Tratando-se, pois, de uma experiência que envolve o pesquisador em um processo criativo que necessariamente atravessa seu corpo vibrátil e converte-o em seu protagonista, é claro que um método que destitui a autoridade do observador como elemento que legitima a produção de conhecimento se torna adequado. A cartografia alude à dissolução do ponto de vista do observador, já que implica que a presença dele, inevitavelmente, promove a separação entre sujeito e objeto, assim como a imposição de um quadro de referência interpretativo separado da experiência (Passos, Kastrup e Escóssia, 2012). É obvio que essa separação entre sujeito e objeto não descreve as particularidades desta pesquisa. Por isso, cartografar, além de acompanhar processos, significa, no contexto desta pesquisa, vivenciar o processo em si.

O projeto $\mathrm{O}$ ator em solidão, assim como a cartografia, parte de uma ideia de pesquisa que não pretende explicar um campo do conhecimento (o que faria o observador com pretensões de objetividade absoluta), mas dar à criação desse conhecimento um lugar determinante. Finalmente, para o cartógrafo, “[...] a cognição é uma máquina autopoiética, isto é, um ato de criação de uma máquina que constitui tanto o polo objetivo quanto o subjetivo do fenômeno cognitivo" (Passos, Kastrup e Escóssia, 2012, p. 121). Igualmente, a cartografia entende o conhecer como fazer, como criação de uma realidade de si e do mundo (Passos, Kastrup e Escóssia, 2012).

Criação e conhecimento, assim, dão-se as mãos constantemente. Isso faz com que se reconheça uma maneira de se aproximar à experiência investigativa quebrando os paradigmas da ciência moderna, $o$ que dá lugar à aparição de outras metodologias. Nesse panorama, a proposta desta pesquisa, na qual o objeto não estava pronto para ser observado, mas precisava ser criado, define um modo de fazer, de agir, de atuar, no qual o conhecimento não está aí para ser descoberto, mas para ser engendrado: 
[...] aproximar conhecimento e criação, afirmar que a ação de conhecer configura ao mesmo tempo, e num movimento de coengendramento, o sujeito e o objeto, o si e o mundo, não é apenas criar um novo conceito de cognição. É um convite a adotar uma certa maneira de estar no mundo, de habitar um território existencial e de se colocar na relação de conhecimento. (Passos, Kastrup e Escóssia, 2012, p. 202)

O fazer desta pesquisa se sustenta, precisamente, na necessidade de ocupar um outro lugar no mundo, diferente do já habitado, com o interesse de encontrar novas formas de expressão, novas maneiras de construir e de criar. A metáfora do encontro às escuras, assim, continua sendo relevante.

O cartógrafo acompanha um processo que, se ele guia, faz tal como o guia de cegos que não determina para onde o cego vai, mas segue também às cegas, tateante, acompanhando um processo que ele também não conhece de antemão. (Passos, Kastrup e Escóssia, 2012, p. 123)

Sobre o assunto da dissolução do ponto de vista do observador, voltaremos mais adiante, quando falarmos da definição de procedimentos.

O fazer desse processo criativo, então, a partir da perspectiva exposta anteriormente, poderia se definir como cartográfico, já que não atinge um método tradicional já testado em outras experiências criativas (ou investigativas), mas sim procura a criação de novos sentidos. Tudo isso com um roteiro que irá se construindo no caminho e que terá tantas alterações quanto a experiência demandar.

Outra das características que pode definir o fazer desta pesquisa como cartográfico é o ponto de partida do desejo. Reconhecer isso representou entender que o ato criativo já tinha começado há muito tempo e que, ao contrário do que pensava, existia, sim, um ponto de partida. Aquelas primeiras intuições, o desejo de desenvolver este projeto de criação e a aspiração de levar ao palco uma inquietação pessoal já constituíam o início da criação. Como assinalam Gilles Deleuze e Claire Parnet (citado por Rolnik, 2006), “[o] desejo é revolucionário, 
porque sempre quer mais conexões, mais agenciamento" (p. 29). A pesquisa teórica que se sustenta neste livro como pressupostos do projeto e a seleção de materiais dão conta dessa série de agenciamentos que começaram a operar a partir do momento em que o desejo iniciou uma movimentação que até agora não se detém.

É interessante, por exemplo, reconhecer que a busca teórica já fazia parte da criação e, embora não estivesse sendo produzida na sala de ensaio, estava alimentando substancialmente o desejo criativo. Tanto é assim que o sustento teórico não só ajudou na definição de procedimentos, mas também encontrou lugar no espetáculo, inclusive como palavra falada. No reconhecimento da teoria como motor da criação e alimento do desejo, encontram-se novas relações com a prática cartográfica. Sobre esse assunto, Rolnik (2006) aponta:

[...] pouco importam as referências teóricas do cartógrafo. O que importa realmente é que, para ele, teoria é sempre cartografia — e, sendo assim, ela se faz juntamente com as paisagens cuja formação ele acompanha [...] Para isso, o cartógrafo absorve matérias de qualquer procedência. Não tem o menor racismo de frequência, linguagem ou estilo. Tudo o que der língua para os movimentos do desejo, tudo o que servir para acunhar matéria de expressão e criar sentido, para ele é bem-vindo. Todas as entradas são boas, desde que as saídas sejam múltiplas. Por isso o cartógrafo serve-se de fontes as mais variadas, incluindo fontes não só escritas e nem só teóricas. Seus operadores conceptuais podem surgir tanto de um filme quanto de uma conversa ou de um tratado de filosofia. O cartógrafo é um verdadeiro antropófago: vive de expropriar, se apropriar, devorar, e desovar, transvalorado. Está sempre buscando elementos/alimentos para compor suas cartografias. Este é o critério de suas escolhas: descobrir que matérias de expressão, misturadas a quais outras, que composições de linguagens favorecem a passagem das intensidades que percorrem seu corpo no encontro com os corpos que pretende entender. (p. 65-66, itálico no original) 
O proceder desta pesquisa encontra nas palavras de Rolnik uma descrição muito próxima. As teorias aqui não representam meras referências para o pesquisador, mas funcionam como operadores da criação. Os conceitos estudados e rastreados de diferentes perspectivas impulsionam uma busca que se traduz finalmente em criação cênica, a qual seria essa paisagem que, como pesquisador, acompanho e protagonizo. Da mesma maneira, e entendendo a teoria como cartografia, esta pesquisa não considera como fontes teóricas únicas os materiais dados pela cultura acadêmica. O leitor já terá percebido as mais variadas origens das fontes mencionadas. Uma revisão rápida das referências bibliográficas permitirá ver como convivem textos da teoria teatral, da filosofia, da semiótica, da literatura e até da cultura religiosa, entre outros, provenientes de livros, artigos, revistas e blogs. Tudo isso sem contar com as referências pictóricas, musicais ou da experiência pessoal, as quais também são consideradas aqui fontes de conhecimento. Enfim, inúmeras linguagens se conjugam para alimentar o desejo criativo.

Uma última qualidade que entende esse fazer como cartográfico é seu caráter processual. Quando se pensa em cartografia, fala-se de “[...] um método processual, criado em sintonia com o domínio igualmente processual que ele abarca. Nesse sentido, o método não fornece um modelo de investigação” (Passos, Kastrup e Escóssia, 2012, p. 77). Da mesma forma que o método da cartografia se constrói no passo a passo, o fazer que definiu a criação do espetáculo unipessoal teve características particulares que foram se construindo no dia a dia da criação. "O método vai se fazendo no acompanhamento dos movimentos das subjetividades e dos territórios" (Passos, Kastrup e Escóssia, 2012, p. 123).

A processualidade define o coração da cartografia, o que evidencia o caráter construtivista da atividade cartográfica (Passos, Kastrup e Escóssia, 2012). Nessa perspectiva, se a cartografia é um procedimento ad hoc, a ser construído em cada caso (Passos, Kastrup e Escóssia, 2012), o fazer aqui descrito não poderia se definir de outra maneira, já que encontra sua razão de ser nessa construção particular que só atinge a regra individual desse processo criativo. Vejamos, pois, como se chegou a essa regra individual. 


\section{A fase do "exercício"}

Segundo Rolnik (2006), “[é] muito simples o que o cartógrafo leva no bolso: um critério, um princípio, uma regra e um breve roteiro de preocupações - este, cada cartógrafo vai definindo para si, constantemente" (p. 67). Quando cheguei pela primeira vez a esse processo, na sala de ensaio, a única coisa que estava no meu bolso era esse roteiro de preocupações do qual fala Rolnik e uma única regra: trata-se de um processo de criação unipessoal, portanto a intervenção de outros participantes estava negada. Critérios e princípios só chegariam depois. Definamos, então, como estava composto esse roteiro.

- Primeira preocupação: a obra que sairia daquele processo teria que demonstrar um dizer já pré-identificado, que estava dado pela necessidade de falar da homossexualidade como experiência reveladora de sentidos. Esses sentidos, no entanto, não estavam claros no início do processo criativo e se definiriam posteriormente.

- Segunda preocupação: não existia um ponto de partida relacionado com a existência de um texto dramatúrgico ou de uma história particular, mas sim existia, desde o começo, a pretensão de criar uma ficção. Para isso, contava-se com alguns dos materiais já sistematizados no capítulo anterior ${ }^{2}$.

- Terceira preocupação: a maneira pela qual se daria forma ao espetáculo também tinha que ser criada no processo, o que representava que não existiam procedimentos concretos na hora de começar os ensaios.

Esse breve roteiro, composto apenas de três preocupações principais, assinalava um caminho que iniciar, mas não revelava a rota para encontrá-lo. Nesse sentido, a terceira daquelas premissas se converteu

2 É importante esclarecer que, das obras de André Gide usadas como materiais criativos, duas são narrativas (um romance e um conto). No entanto, o que aparece no espetáculo dessas histórias se mistura com outras histórias provenientes de outras origens e, portanto, não ocupam um lugar central na criação. 
na mais "preocupante". Seu desenvolvimento exigia a definição dos procedimentos do ato criativo, o que, em outras palavras, seria o que daria as particularidades do fazer desse processo. Como iniciar? Só aparecia no meu panorama aquele imperativo: faça, faça, faça... Portanto, comecei a fazer.

Esse primeiro fazer nesse processo de criação, obviamente, não era o fazer que daria forma ao espetáculo, mas já começava a ter as características disso que chamo de fazer cartográfico. Tratava-se de um fazer preparatório, cujo propósito era preparar o terreno. Esse tipo de fazer é chamado por Pareyson de "exercício". Assim o define:

[o] exercício é essencialmente um processo de interpretação produtiva da matéria artística: é fase de preparação, em que se trabalha sem a pretensão ou o intuito de produzir a obra, mas só para realizar um "estudo" que lhe favoreça o surgimento. É uma fase de pesquisa e teste, em que se examinam as próprias possibilidades e as da matéria. É o momento em que se tenta uma técnica codificada para tentar incorporá-la inventivamente em uma direção formativa; em que se procura fazer emergir de um estilo adotado novos problemas e novas possibilidades explorando regiões inexploradas ou reinventando regras já aplicadas com sucesso; em que se vislumbra a atividade intrínseca de uma matéria virgem ou herdada para dela extrair desenvolvimentos possíveis ou inéditos; em que se põe à prova a capacidade sugestiva ínsita na mais imprevisível aplicação ou na mais clara violação de certos cânones tradicionais. (Pareyson, 1993, p. 83-84)

Da mesma maneira como apresenta Pareyson, essa fase preparatória que iniciou o processo criativo tinha o intuito de criar as bases do fazer formativo posterior. Como fase de pesquisa e teste, tratava-se de acondicionar o corpo para a criação do espetáculo. Contudo, esse acondicionamento não se deve entender só como a atividade usual no exercício do ator, isto é, aquecimento corporal e vocal, mas também como adubo do território criativo.

Entender o exercício como fase preparatória para a aparição da matéria artística me permitiu partir da experiência técnica conhecida 
para vislumbrar as possibilidades que, como artista, tinha na descoberta do meu fazer formativo individual. Adubar o terreno representava facilitar que as condições para a atividade formativa chegassem e que se começasse a descartar os procedimentos que não atingiriam as necessidades da nova proposta.

Nesse contexto, o acondicionamento corporal foi ganhando espaço à medida que os ensaios iam se desenvolvendo. Começavam com alongamentos e exercícios de aquecimento das articulações e de respiração, os quais deixavam o corpo em uma situação de abertura que ampliava estados de alerta. Isso me permitiu entender também que os materiais de trabalho que tinha determinado até aquele momento só seriam manipuláveis por meio da experiência corpórea e que o exame das próprias possibilidades da matéria das quais fala Pareyson, no caso da prática do ator, só seria viável a partir da descoberta das possibilidades do próprio corpo.

Além das possibilidades do corpo como matéria maleável pela qual perpassa a experiência do meu eu ator, a fase do exercício também foi o espaço para tentar as primeiras aproximações à criação cênica. Como assinala Pareyson na citação anterior, era o momento de testar os procedimentos já conhecidos e tentar dar a eles uma direção formativa. Para isso, contava com a técnica que tinha me acompanhado por muitos anos no meu ofício interpretativo. Recorri, assim, a vários dos exercícios sistematizados por Jorge Eines em suas publicações, principalmente no seu livro La formación del actor: introducción a la técnica (1988). Trata-se de um livro que tem a pretensão de reunir uma série de práticas que definem o desenvolvimento sequencial e evolutivo de uma aula de interpretação.

Exercícios de concentração, de reconhecimento do espaço, de observação, de memória emotiva, de relaxação, de ativação sensorial, de criação de imagens, de objeto imaginário, enfim, de múltiplas possibilidades para dispor o corpo e a atitude para a experiência cênica foram testados e desenvolvidos com a intenção inicial de se converter em pontos de partida para a criação de primeiras cenas ou trechos 
da obra ${ }^{3}$. No entanto, nenhum desses exercícios, pelo menos não diretamente, conduziram à criação de nenhuma sequência ou cena que fosse usada depois como parte do espetáculo unipessoal. O encontro às escuras continuava avançando em uma dinâmica que não parecia encontrar a luz.

Embora a sensação que produziam aquelas práticas que não conduziam à consolidação de uma forma fosse de frustração, a fase de exercício foi fundamental para consolidar um ambiente que cada vez mais estava se fortalecendo como terreno apto para a aparição do novo fazer que há algumas semanas tentava encontrar. De novo, as palavras de Pareyson apareceram para apaziguar a angústia daquela aparente infertilidade criativa.

Não é portanto nem inútil nem estéril trabalho o do exercício, em que se aguilhoa a letra para lhe evocar o espírito, em que se prepara a matéria para a vinda da forma, em que se aprestam os materiais para o ato de catalisação, em que se afina a vista para que saiba reconhecer o momento ansiosamente esperado, em que se fecunda a memória e se inova a tradição. Tem o exercício, certamente, um aspecto paradoxal, porque é um fazer que não consegue ainda, verdadeiramente, "fazer"; é elaboração de matéria em que a matéria não é ainda, propriamente, artística; é exercício de estilo, em que o estilo não consegue ainda ser, imperiosamente, modo de formar. Mas no exercício a disciplina pode tornar-se criadora, a assiduidade pode fazer-se invenção, o esforço pode traduzir-se em descoberta, e a matéria ser sugestiva: tudo isso é claro, logo que se pensa no conceito de um "espera" que é por si mesma atrativa e suscitadora, fértil e evocativa. (Pareyson, 1993, p. 84-85)

Contrariamente ao que eu pensava naquele momento, não passou muito tempo antes que descobrisse que a fase de preparação, a do exercício,

3 Seguindo a única regra predefinida no processo criativo, vale a pena esclarecer que se escolheram exercícios que pudessem ser desenvolvidos de maneira individual, descartando aqueles que precisassem do estabelecimento de relações com outra pessoa. 
era realmente uma etapa suscitadora. Era no meio dela que encontraria as primeiras luzes sobre o que definiria o modo de proceder do fazer artístico. Meu corpo estava se dispondo para o advento da forma. Estava à espera daquele momento "em que se fecunda a memória e se inova a tradição" (Pareyson, 1993, p. 84).

Esse momento chegou de maneira muito parecida com a que me trouxe a primeira ideia de fazer da solidão um espaço criativo. No primeiro capítulo, narra-se como no meio da experiência de La navidad de Harry (Figura 2) apareceu a ideia de começar este projeto: por abdução. Esse conceito, relacionado com a intuição, faz parte dos pressupostos do processo criativo e reconhece uma forma de se aproximar ao conhecimento e à descoberta de novas possibilidades. No campo da arte, trabalha-se muito a partir da intuição. No caso particular desse processo criativo, foi fundamental entender seus alcances para definir procedimentos operacionais e dar forma ao espetáculo definitivo.

As mudanças mais importantes no modo de proceder durante a etapa de ensaios sempre se deram por "revelações" adutivas. Mas estas só começaram a aparecer depois que o ambiente daqueles ensaios e o meu próprio corpo encontraram um estado de abertura a essas possibilidades. De novo, prova-se a importância do período do exercício.

Pareyson fala de intuição na sua teoria da formatividade de maneira muito acertada e próxima ao que se desenvolveu nesse processo de criação. O reconhecimento das fortalezas intuitivas do artista na consolidação da forma é fundamental na fala do esteta. Assim, ele a nomeia como insight:

[m]esmo quando o insight me sobrevém de súbito, e me surpreende apesar de esperá-lo, assim que o capto compreendo que é justamente o que esperava, que é meu insight, minha intuição, que só a mim poderia ocorrer e que não poderia deixar de me ocorrer. (Pareyson, 1993, p. 80, itálico no original)

O insight é, sob a perspectiva de Pareyson, uma espécie de revelação que chega ao artista e que antecipa a aparição da forma. Nesse processo de pesquisa/criação, poderia, então, afirmar que o primeiro insight surgiu 
justamente no meio do processo de La navidad de Harry, quando a força da intuição me permitiu captar que aquela situação que me parecia desfavorável naquele momento constituiria, posteriormente, uma forma de trabalho e a descoberta de novas inquietações. Por enquanto, voltemos a Pareyson para encontrar uma definição mais clara do que seria o insight.

Antes do advento da forma, algo existe que a anuncia e faz pressagiar, que tende a ela e cria a expectativa em torno dela, que dirige e orienta o artista em sua produção. E esse algo é o "insight" no qual a forma, que também só existirá quando o processo terminar, já atua e age guiando aquele mesmo processo de onde emergirá na sua totalidade. (Pareyson, 1993, p. 73)

Portanto, o insight é antecipação, prenúncio, expectativa da forma. É esse algo que permite intuir o que será a forma que o processo de produção artística tenta alcançar. Nesse sentido, ele é uma espécie de guia na hora de encontrar os procedimentos que conduzirão o fazer do artista.

Assim como acontece com o conceito de intuição, o qual pode sofrer a desconfiança do cientista ortodoxo, Pareyson reconhece a impossibilidade de tratar o insight como conhecimento preciso. Por isso, além de expectativa e outras palavras que podem funcionar como sinônimos de insight, o autor adiciona outras tão pouco gratas para o paradigma da ciência moderna como adivinhação e presságio.

E essa antecipação da forma não é propriamente um conhecimento preciso nem visão clara, pois a forma só existirá quando o processo se concluir e chegar a bom termo [...] Trata-se, na verdade, de presságio e adivinhação, em que a forma não é encontrada e captada, mas intensamente esperada e ansiada. Mas esses pressentimentos, embora intraduzíveis em termos de conhecimento, agem na execução concreta como critérios de escolha, motivos de preferência, rejeições, substituições, impulsos e arrependimentos, correções, revisões. Ou melhor, o único modo de dar-se conta deles é precisamente essa sua eficácia operativa, 
pela qual no processo de produção o artista sem cessar julga, avalia, aprecia, sem saber de onde na verdade procede o critério dos seus juízos, mas sabendo com certeza que ele, se deseja chegar a bom termo, deve agir conforme apreciações assim orientadas. (Pareyson, 1993, p. 75)

Felizmente, essa impossibilidade de tratar o insight como conhecimento preciso é, sim, no campo da arte, bem apreciada. O que Pareyson está colocando sobre a mesa é o reconhecimento do valor das capacidades intuitivas do artista. Essa certeza descrita no final da citação é precisamente intuição. $\mathrm{O}$ artista não identifica claramente as fontes dessa certeza, mas acredita na sua sensibilidade para confiar a ela o caminho a seguir.

Assim, Pareyson outorga um lugar determinante ao insight na criação artística. De fato, assinala que "[o] verdadeiro artista é aquele que encontra sempre insights em torno de si, não precisa procurá-los: basta-lhe olhar em torno de si para logo ser assediado por sugestões não solicitadas" (Pareyson, 1993, p. 80). Esse tipo de sugestões se relaciona com aquela ideia romântica de inspiração: o artista como aquele ser que constantemente recebe estímulos à atividade criadora ${ }^{4}$. Mas, como já se tem comprovado na prática artística, a inspiração não faz o artista; a obra só pode chegar a bom termo a partir da disciplina e do trabalho constante. É por isso que Pareyson (1993) afirma que,

[s]em o propício ambiente da busca artística, o único em que pode desenvolver-se e frutificar, a própria vitalidade da semente se torna estéril e morre. A intencionalidade do insight ou da intuição, portanto, atua na e através $d a$ atividade do artista, que é sua única sede possível. (p. 82, itálico no original)

Essas palavras de Pareyson explicam muito bem o motivo pelo qual este projeto de pesquisa e criação encontrou sua origem no meio de

4 Isso também poderia se aplicar ao exercício do cientista. Finalmente, como assinala Umberto Eco (1989), e como foi citado no primeiro capítulo deste livro, esse tipo de inspirações é típico de descobertas científicas revolucionárias. 
outro processo de produção artística, já que só nesse ambiente pode aparecer a inspiração tão anelada por alguns românticos. No mesmo sentido, justifica ainda mais a etapa do exercício, na qual apareceu o que poderíamos localizar como o segundo insight determinante na consolidação deste processo criativo.

\section{A construção de um espaço poético}

No meio daquele ambiente de espera que representou a etapa do exercício, que afinou as condições da sala de ensaio e do meu próprio corpo para o advento da forma, apareceu uma pergunta cuja resposta mudou o desenvolvimento dos ensaios: "o que é que eu estou fazendo aqui?”. Eu sabia que estava atrás da criação de um espetáculo unipessoal, mas não foi essa a resposta que chegou naquele momento, e sim a seguinte: "eu estou construindo meu espaço poético". Essa resposta conta com todas as características que definem o insight e se converteu na grande revelação deste processo criativo.

Imediatamente, tudo se esclareceu. Essa resposta, que na atualidade parece uma obviedade, estava formulada em termos que convidavam à ação. Desde o começo desta pesquisa, era claro que minha grande busca era a do encontro com o meu eu artista, com o ator que quer falar por conta própria, que tem algo para dizer; mas, quando essa intenção foi colocada em termos de lugar (espaço poético) e de ação (construir), soube que, naquele primeiro insight, já estava a essência dos procedimentos que dariam forma ao meu desejo. No entanto, precisei de mais um insight para atingir aquele novo esclarecimento.

Pois bem, já que estava aí para construir meu espaço criativo, não tinha outra opção que traduzir aquilo em materialidade. Como assinalei no segundo capítulo, o entendimento da arte como experiência do mundo físico, e não como abstração, me levou a dispor todos meus materiais de tal maneira que eu construísse realmente um espaço que me convidasse à criação. Foi assim como todas as pinturas, as leituras e os objetos que representavam a experiência autobiográfica que queria usar como material criativo encontraram na sala de ensaio um lugar físico particular. A sala de ensaio, antes o espaço vazio disposto para o training e a preparação do ator, converteu-se em um espaço que tinha 
mais a aparência do ateliê de um artista plástico. Livros, fotografias e pinturas encontravam-se distribuídos pelo chão. Em um dia, entravam alguns desses objetos, em outro saíam para abrir espaço à chegada de novos. O computador também entrava e saía dali. Às vezes para colocar uma música, às vezes para procurar materiais nas minhas redes sociais ou na internet.

Essa necessidade de construção do espaço poético também tem uma íntima relação com a lógica cartográfica. Uma das pistas do livro organizado por Passos, Kastrup e Escóssia se intitula, precisamente, “Cartografar é habitar um território existencial”. Assim, a "instalação da pesquisa cartográfica sempre pressupõe a habitação de um território" (Passos, Kastrup e Escóssia, 2012, p. 135). No sentido dado nesta pesquisa, o espaço poético construído atinge a categoria de território existencial porque não se limita unicamente a ocupar um espaço já dado pelas circunstâncias, mas representa uma aposta existencial na qual o pesquisador-criador envolve todo seu ser.

Cartografar é sempre compor com o território existencial, engajandose nele. Mas sabemos que o processo de composição de um território existencial requer um cultivo ou um processo construtivo. Tal processo coloca o cartógrafo numa posição de aprendiz, de um aprendiz-cartógrafo. Nesse processo de habitação de um território, o aprendiz cartógrafo se lança numa dedicação aberta e atenta. Diferente de uma pesquisa fechada, o aprendiz-cartógrafo inicia sua habitação do território cultivando uma disponibilidade à experiência. (Passos, Kastrup e Escóssia, 2012, p. 135-136)

Foi precisamente na habitação desse território existencial, desse espaço poético, que o fazer formativo encontrou sua própria lógica. Habitar esse espaço com mais características iniciais de ateliê do que de cenário, me colocou na posição de aprendiz. Cada deslocamento pela sala me enfrentava com uma leitura, com uma imagem, com um objeto que suscitava a criação. Como se assinala na citação anterior, habitar esse território implicava um processo construtivo. Aparecia assim, de novo, essa ideia de aventura: “[...] para o aprendiz-cartógrafo, o campo territorial não tem a identidade de suas certezas, mas a paixão de uma aventura” 
(Passos, Kastrup e Escóssia, 2012, p. 138). Estava na hora, pois, de começar uma nova aventura, a da composição.

A construção daquele espaço poético me deu, finalmente, as ferramentas que estava procurando para encontrar os procedimentos criativos que me levariam à composição efetiva do espetáculo unipessoal e ajudou-me a corroborar que as regras que conhecia do campo do ofício não seriam as adequadas para o novo caminho que empreendia. A pista cartográfica assim o confirmava: "[a] habitação de um território existencial está mais ligada a uma disposição de composição do que à execução de normas técnicas” (Passos, Kastrup e Escóssia, 2012, p. 148).

No dia 19 de março de 2013, às 14 horas, na sala 5 da Escola de Teatro da Universidade Federal da Bahia, na cidade de Salvador (Bahia), fiz uma apresentação daquele espaço poético no contexto da disciplina Processos de encenação, conduzida pela professora doutora Sonia Rangel. Foi a única experimentação que se fez com público durante todo o processo criativo. Aproveitando uma exigência da aula, decidi sair da sala de ensaio para "testar" as potencialidades daquele espaço poético. Como se pode observar na seguinte fotografia (Figura 10), criou-se um espaço no qual se penduraram objetos que correspondiam a vários dos materiais assinalados no capítulo anterior. A partir deles, desenvolveu-se uma experiência de teste de possibilidades cênicas. 
Figura 10. Apresentação pública do espaço poético. 19 de março de 2013.

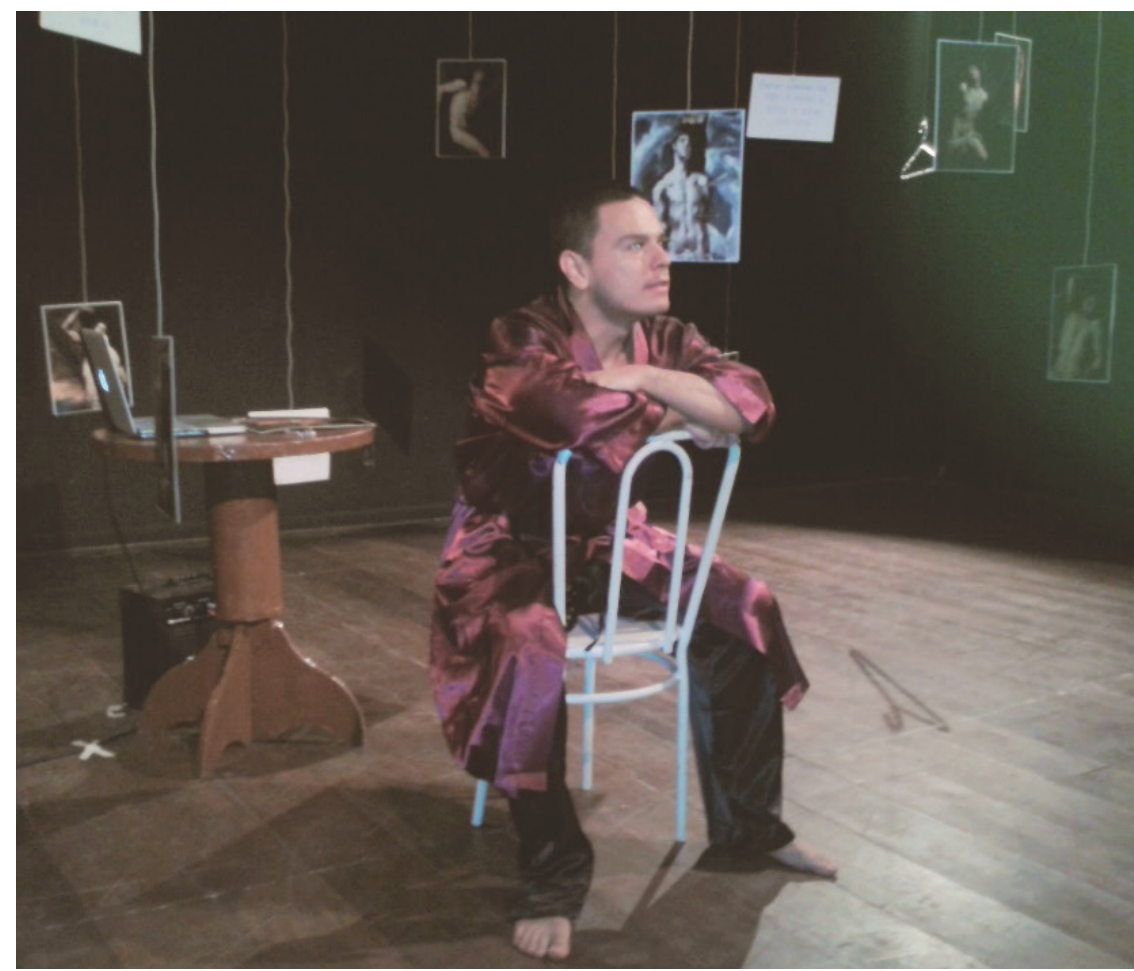

Fotografia: Germán Guevara González.

Várias versões da representação pictórica de são Sebastião (27 em total) - correspondentes a autores de diferentes nacionalidades, épocas e estilos-, fotografias pessoais e fragmentos dos textos de André Gide foram pendurados em um espaço cênico delimitado, visualmente, por uma atmosfera de luz e, sonoramente, por três peças musicais -o Erbarme Dich, Sein Gott, de Johann Sebastian Bach, a Havaneira, de Georges Bizet, e uma versão musical do poema de Federico García Lorca Gacela del amor que no se deja ver, cantado por Carlos Cano. Sobre o papel que desempenharam essas músicas no espetáculo, falarei mais adiante. Por enquanto, o registro da atividade desenvolvida naquele 19 de março é apresentado aqui porque resume de boa maneira o que começou a ser desenvolvido na sala de ensaio. 
Foi a partir da construção desse espaço poético que o espetáculo unipessoal iniciou o processo de encontrar a forma. Para começar, os materiais de trabalho obtiveram uma presença determinante na ativação de suas funções como instâncias criativas. Além disso, evidenciaram o que se converteu no princípio orientador dos procedimentos criativos: a multiplicidade.

Inspirado nas propostas de Ítalo Calvino para o século XXI, entendo o princípio a partir das múltiplas e complexas maneiras de abordar a criação artística. Embora Calvino use o termo para entender os alcances da literatura contemporânea, o assunto pode atingir as diferentes expressões artísticas.

Calvino (1990) entende a multiplicidade "[...] como enciclopédia, como método de conhecimento e principalmente como rede de conexões entre os fatos, as pessoas, entre as coisas do mundo" (p. 121). Embora esteja se referindo ao caso particular do romance, esta pesquisa toma essa ideia para entender a construção da obra artística em geral, o que está muito relacionado com a seleção de materiais que se apresentou no capítulo anterior. Em definitiva, a ideia de enciclopédia tem uma relação direta com a de acervo e a de imaginário. Além disso, a habitação do espaço poético evidenciou minha pequena enciclopédia sobre a homossexualidade e pôs cada um dos materiais em uma posição que, interconectados de múltiplas formas, pareciam dar uma lógica específica a esse imaginário sobre a homossexualidade que até aquele momento era só uma série de referências dispersas.

Foi nesse momento que entendi, pela primeira vez, como era que meu imaginário pessoal tinha se nutrido de diversas fontes. A maneira como apareciam organizadas —ou desorganizadas naquele espaço- permitia vislumbrar a singularidade que eu mesmo estava lhes dando quando foram convocadas ao ato criativo. O que era múltiplo, paradoxalmente, estava me mostrando uma unidade possível. Estaria confundindo os termos? Seria possível que um princípio aparentemente contrário à unidade servisse para dar forma a um espetáculo unipessoal?

Calvino (1990) se faz uma pergunta similar quando tenta concluir suas reflexões sobre a multiplicidade. "Alguém poderia objetar que quanto mais a obra tende para a multiplicidade dos possíveis mais se 
distancia daquele unicum que é o self de quem escreve, a sinceridade interior, a descoberta da sua própria verdade” (p. 138). A resposta que encontra está dada, novamente, pela ideia de enciclopédia, na qual reconhece que cada um de nós é o resultado de uma combinatória de experiências. Mas essa combinatória não faz nada mais do que definir o ser único que as contém. Na multiplicidade de discursos e experiências que atravessam meu imaginário, acabei descobrindo precisamente o que me define como sujeito particular.

Tratava-se, então, de unir pontos, de criar uma estrutura a partir da multiplicidade de referências que coabitavam no meu espaço poético. Para o caso desta pesquisa, faltavam criar os fios de minha própria criação, essa rede de conexões que ilustram tanto o processo criativo como o de agenciamento de teorias na construção também de um campo de conhecimento nas artes. É interessante como, em uma perspectiva parecida, Calvino (1990) usa a imagem de fio para definir o conhecimento a partir do princípio que nos ocupa. "O conhecimento como multiplicidade é um fio que ata as obras maiores” (p. 130).

Calvino coloca sobre a mesa a necessidade de entender que, no mundo atual, enquanto a ciência se especializa cada vez mais, a literatura (eu estendo suas considerações ao campo artístico em geral) tem o grande desafio de "[...] saber tecer em conjunto os diversos saberes e os diversos códigos numa visão pluralística e multifacetada do mundo" (Calvino, 1990, p. 127). Eis como pode ser aplicado o uso dos materiais provenientes do imaginário, sendo este sempre produto daquela visão pluralística e multifacetada e, no entanto, apropriação particular/individual do mundo.

A partir dessa ideia de multiplicidade, entendi que o fazer que permitiria dar forma ao meu espetáculo unipessoal estava justamente nesse tecer. Tratava-se de interligar os diferentes materiais e criar uma trama que me permitisse coletivizar essa minha singularidade, aquela que é produto de uma apropriação particular do mundo. Isso, por sua vez, fazia com que o processo me desse uma clareza sobre o princípio de multiplicidade, o qual fazia parte do processo criativo, do ato de formar, mas que cada vez mais se decantava na consolidação de uma obra, de um espetáculo verdadeiramente unipessoal. A multiplicidade como princípio da criação se concretizava no uso de 
múltiplas referências e experiências —meus materiais provenientes do imaginário-, mas ela não era outra coisa que expressão do self do artista:

[...] quem nos dera fosse possível uma obra concebida fora do self, uma obra que nos permitisse sair da perspectiva limitada do eu individual, não só para entrar em outros eus semelhantes ao nosso, mas para fazer falar o que não tem palavra, o pássaro que pousa no beiral, a árvore na primavera e a árvore em outono, a pedra, o cimento, o plástico... (Calvino, 1990, p. 138)

E é justamente nesse convite a dar a palavra àquilo que não a tem que Calvino define a multiplicidade à qual o artista está sendo convocado. Aquela intuição inicial de que não bastaria só minha experiência particular para dar forma a um espetáculo que pretendia falar da homossexualidade encontrou validade na perspectiva de Calvino. $\mathrm{O}$ ato criativo, como aventura, sempre convida o artista à busca constante. No meu caso, essa busca pelos materiais que habitariam meu imaginário sobre a homossexualidade me levou ao empreendimento de uma viagem que diversificou extraordinariamente minha experiência, mas que, sem prevê-lo, acabou sendo uma viagem interior.

Assim, finalmente, criou-se um espetáculo unipessoal que encontrou na multiplicidade seu princípio gerador, mas era uma multiplicidade que dava conta de uma singularidade, como a de qualquer ser humano, limitada por experiências particulares. Contava-se com alguns materiais, com uma pequena enciclopédia que pretendia abranger um grande tema. Mas a pequenez daquele acervo não era impedimento para a abordagem de tão ambiciosa empresa. De fato, Calvino continuava apoiando minha determinação. "A excessiva ambição de propósitos pode ser reprovada em muitos campos da atividade humana, mas não na literatura. A literatura só pode viver se se propõe a objetivos desmesurados, até mesmo para além de suas possibilidades de realização" (Calvino, 1990, p. 127). Torna-se desnecessário o esclarecimento da aplicação para todas as outras artes.

$\mathrm{Na}$ excessiva ambição do artista, da criação em si, a multiplicidade encontra outra das suas nuanças. A inapreensibilidade do mundo e do 
conhecimento, a incapacidade de concluir, a pluralidade das linguagens como meio de encontrar a verdade e a necessidade de impor regras para o ato criativo são outras das nuanças que Calvino (1990) assinala quando fala do princípio de multiplicidade e de uma aposta por uma arte que entenda o mundo como "um sistema de sistemas" (p. 127). Todas essas condições se condensam em uma ideia de criação artística, na qual “[...] não é mais pensável uma totalidade que não seja potencial, conjetural, multíplice” (Calvino, 1990, p. 131).

Esclarecido o termo multiplicidade como princípio orientador da criação do espetáculo unipessoal, só resta apresentar os procedimentos que esse esclarecimento permitiu definir. Na seguinte parte, descrevem-se o espetáculo como tal e os procedimentos procedentes dessa ideia de multiplicidade que levaram à sua estreia.

\section{Meus caros amigos}

No dia 11 de setembro de 2013, no Teatro Martim Gonçalves, da cidade de Salvador (Bahia), estreou-se o espetáculo unipessoal Meus caros amigos (Figura 11). O espetáculo conta as experiências de um homem de meia-idade que reúne seus amigos para revelar detalhes da sua vida íntima, os mesmos que antes não tinha tido a coragem de fazer públicos. Por circunstâncias que só se desvendam no final da peça, o homem se sente obrigado a falar de uma homossexualidade que manteve secreta durante toda a sua vida, escondida à sombra de um casamento heterossexual. $\mathrm{O}$ espetáculo oferece uma rápida passagem pelos últimos anos da experiência vital do homem e converte a plateia nesse grupo de amigos que foram convocados para escutar suas confissões. 
Figura 11. Meus caros amigos. Estreia: 11 de setembro de 2013. Teatro Martim Gonçalves. Salvador (Bahia)

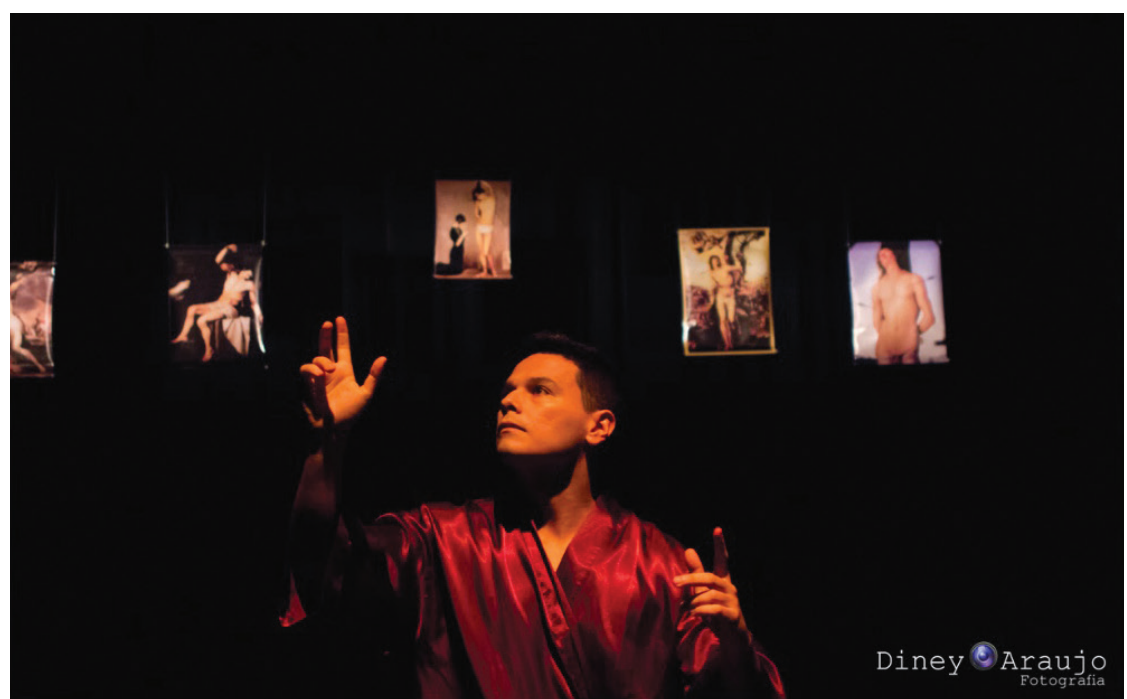

Fotografia: Diney Araujo.

A peça acontece em um cenário que tem bastante semelhança com a lógica do espaço poético que se construiu na sala de ensaio e inclui novos elementos que foram chegando conforme a ficção foi se consolidando. Como já foi assinalado, o texto não partiu de história nenhuma, por isso ter chegado a essa ficção constituiu um grande desafio que respondia à segunda das preocupações que conformavam o roteiro inicial de preocupações. Na continuação, serão expostos como se consolidou essa ficção e como elementos como palavra, cenário, sonoplastia, figurino, entre outros acabaram de dar forma à obra artística que esta pesquisa deu à luz.

\section{Consolidação de uma fiç̧ão}

Uma vez entendido o princípio de multiplicidade como norteador do processo criativo, a utilização dos materiais se fez cada vez mais fluída e dinâmica. O primeiro aspecto importante que deve ser considerado se refere a que espetáculo já concluído evidenciou a ideia de unidade que se apresentou na parte anterior: finalmente, o espetáculo conta a 
história de um homem, mas não se trata de uma única história, senão de uma série de micro-histórias que confluem em uma única existência. Entender, então, que não existia uma ficção só, mas várias que se uniam para criar a unidade do espetáculo, esclareceu a ideia de que seria uma rede de histórias o que daria a forma definitiva da obra. A multiplicidade, nessa medida, confirma-se como princípio criativo na composição do espetáculo, mas já, como obra, ela abriu espaço para a unificação no formar.

Eu estava interessado em contar a história de um homem que sente a necessidade de ocultar sua verdadeira natureza por conta de uma sociedade que, aparentemente, "aceita" a homossexualidade, mas só como experiência íntima, fora da vida pública. No entanto, contar a história de alguém a partir de sua pergunta pela sexualidade envolve necessariamente a interligação com as histórias de outros. Isso fez com que o espetáculo acabasse contando várias histórias a partir das experiências com esses outros. Nessa lógica, uma ficção era a confluência de múltiplas ficções.

O indivíduo que acabou se retratando, como qualquer ser humano, não podia representar uma ideia fechada de sujeito. O homem acabou sendo apresentado como profissional, filho, esposo, amigo, amante; contou suas histórias em diferentes momentos da sua vida - a experiência intelectual, a doença, a condição de estrangeiro- e envolveu suas vivências de atmosferas que fazem referência a diferentes estados anímicos - a felicidade, a culpa, a impaciência-. Essa multiplicidade de estados e momentos foi um exercício consciente na construção da ficção que, de alguma maneira, tinha a intenção de corresponder ao princípio gerador do ato criativo. Demandou a criação de uma rede que interligava, de diferentes maneiras, os diferentes materiais involucrados. Cada micro-história unia uma referência literária com outra pictórica, autobiográfica ou, inclusive, teórica, formando uma trama que unia pontos distantes, amarrando uma estrutura que acabou se autossustentando.

Essa estrutura, no entanto, não se concebeu no começo como totalidade, mas a partir de uma lógica fragmentada. A multiplicidade não divide a unidade, mas a diversifica. Não foi, então, a construção 
de uma ficção dividida em várias histórias, mas o encontro de vários fragmentos que, posteriormente, deram forma final à grande ficção.

A primeira história que se desenvolveu, por exemplo, é a de um encontro do protagonista com um jovem trabalhador de uma fazenda. Chegou-se a essa microficção a partir da união de dois materiais principais: O pombo torcaz, de André Gide, e São Sebastião de Agnolo Bronzino (Figura 9). A partir da interação com a leitura do conto de Gide e com as qualidades físicas da figura retratada por Bronzino, criou-se a ficção que tinha como personagem central Fernando, um adolescente que está experimentando o despertar da sua sexualidade e que, aparentemente, tem seu primeiro encontro homoerótico com o protagonista do espetáculo.

Essa ficção, sendo a primeira a ser desenvolvida, no entanto, é uma das últimas que se narra no espetáculo unipessoal. Isso porque cada uma das microficções respondeu a diferentes tipos de associações e só começaram a ter uma ordem particular quando a maioria já tinha alcançado uma aparência inicial.

Do mesmo modo que o conto de Gide e a pintura de Bronzino se encontraram para dar forma à história de Fernando, diferentes interligações começaram a dar forma a outras histórias e à ficção completa. A confluência entre São Sebastião de Giovanni Bazzi (Figura 6), uma vivência autobiográfica relacionada com minha experiência como docente universitário, algumas das premissas expostas por Gide em seu ensaio Corydon e a história do autor do quadro, por exemplo, deram vida a outra das microficções, na qual o protagonista insinua um relacionamento com um aluno.

A maneira como são apresentadas as duas histórias no espetáculo unipessoal também torna evidente o recurso usado de colocar o protagonista em diferentes momentos ou estados anímicos de sua existência. Além disso, propõe-se multíplice no uso dos recursos narrativos. A de Fernando, por exemplo, é narrada diretamente para a plateia, quase como um flashback, enquanto a do aluno é representada no contexto de uma aula, no qual os espectadores passam de ser os amigos que escutam a confissão do protagonista a ser seus alunos.

Falando sobre a diversidade de métodos como qualidade das obras modernas, Calvino (1990) diz que “[...] os livros modernos 
que mais admiramos nascem da confluência e do entrechoque de uma multiplicidade de métodos interpretativos, maneiras de pensar, estilos de expressão" (p. 131). Cada uma das histórias que compõem a totalidade da ficção apresentada em Meus caros amigos representa um acervo diferente, uma forma de pensar distinta e uma escolha expressiva variável; no entanto, tudo fazendo referência a um acervo, uma maneira de pensar e uma forma de expressão particulares que definem uma apropriação do mundo única e pessoal.

Figura 12. Construção da ficção a partir do princípio de multiplicidade

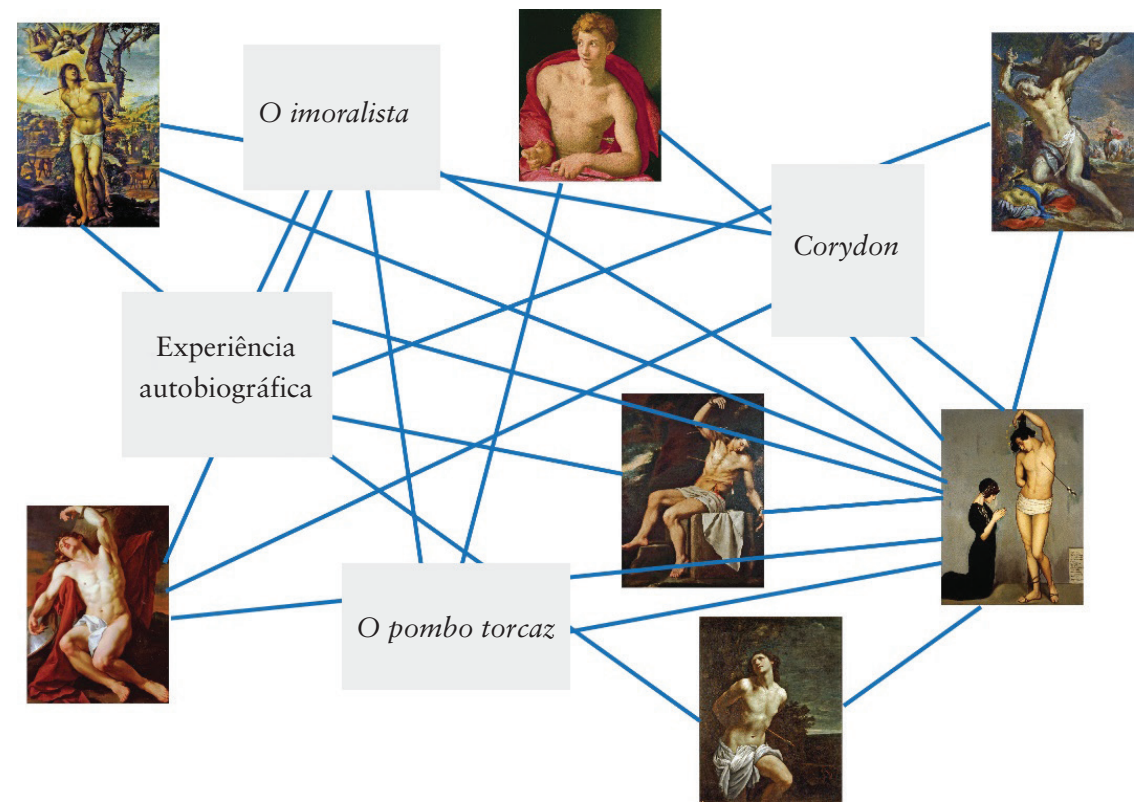

$\mathrm{Na}$ Figura 12, ilustra-se a trama que mostra as diversas interligações que constroem a rede da ficção apresentada no espetáculo. Vê-se como, para seguir na figura a lógica do narrado acima, a obra de Bronzino e O pombo torcaz se unem com uma linha que evidencia sua interconexão, o que também pode se observar no caso do são Sebastião de Bazzi interligado com Corydon e a experiência autobiográfica. No entanto, o que está apresentada na Figura 12 é a rede que compõe a ficção geral do espetáculo. Por isso, observa-se que todos os 
materiais acabam criando uma trama complexa na qual cada associação conduz a novas interligações. É, assim, a maneira múltipla de criar uma unidade.

$\mathrm{Na}$ etapa inicial, a construção da ficção partiu do desenvolvimento de microficções que acabaram sendo fragmentos do que seria a unidade do espetáculo. O procedimento para sua criação foi o mesmo que se descreveu nos dois exemplos anteriores: por interligação de materiais. Cada fragmento alcançou vida própria e independente. Mas chegou o momento em que se fez necessário encontrar uma maneira de conectálos. Os meios que possibilitaram a criação dessas microficções, de novo, permitiriam encontrar o eixo que se procurava. Sobre como o fragmento pode dar as luzes para a conclusão de um processo artístico, Pareyson (1993) assinala:

[...] o artista sabe que, do ponto de vista de seu trabalho, se chega a construir e compor só através da seleção e da escolha, e assim ele deve interrogar as mudas pretensões do fragmento para conseguir atingir ao que lhe falta, e dirigir as rejeições de modo a alcançar a conclusão do processo só através de um progressivo fechamento, em que a eliminação de uma possibilidade reclama em cada caso a supressão de outras. (p. 78-79)

Os fragmentos já desenvolvidos tinham evidenciado a interligação de materiais como procedimento criativo das ficções, o que acabou dando forma ao princípio de multiplicidade como se apresentou na Figura 12. A chave, então, encontrava-se nesse mesmo procedimento. Assim, por exemplo, cada um dos sebastiães acabou sendo associado com um personagem e uma história, o que demandou que a extensa quantidade de pinturas que compunham o espaço poético apresentado em março de 2013 passasse de 27 a só 7 na última versão do espetáculo ${ }^{5}$.

5 No capítulo anterior, expôs-se como a figura de são Sebastião se constituiu fundamental como parte da consolidação do meu imaginário sobre a homossexualidade. A maneira como essa imagem se converteu em material de trabalho, diversificada nas muitas versões pictóricas usadas, mostra uma vez 
Esse processo de seleção dos quadros que finalmente ficaram até a consolidação do espetáculo unipessoal exigiu um processo de escolha longo, no qual, aos poucos, iam se descartando pinturas conforme iam se desenvolvendo as microficções. Os que foram associados a essas histórias são os que aparecem na Figura 12. Assim, cada são Sebastião tem correspondência com um amante e com uma microficção. Um deles se destaca sobre os outros por ter se convertido em referência do protagonista do espetáculo. Trata-se do Sebastião do quadro de Ángel Zárraga, Ex-voto, Martirio de San Sebastián (Figura 7). De todas as versões do santo, a pintura de Zárraga me causou uma inquietação particular: era a única que tinha uma presença feminina tão forte como companhia (em alguns quadros, apareciam mulheres piedosas em segundo plano, mas nenhuma tinha uma presença semelhante à de Zárraga).

Como ícone da cultura gay, são Sebastião representa um ideal de beleza masculina apolínea que, já sabemos, define muitos dos cânones do homoerotismo. O de Zárraga é bastante fiel a essa tradição, o que contrasta categoricamente com a presença da mulher em atitude devota que o acompanha. Essa composição do quadro imediatamente criou uma associação que persistiu até o final do processo criativo, no qual se interligou a pintura com o romance $\mathrm{O}$ imoralista e com o interesse particular do que eu queria apresentar no espetáculo. O quadro, da perspectiva do processo criativo, condensava tanto a referência homoerótica como a ideia de casal conformada pela união entre um homem e uma mulher. Como se pode observar na figura, o quadro de Zárraga é o que mais linhas de união tem com os outros materiais e, precisamente por esse motivo, acabou se convertendo no eixo que procurava para unir as micro-histórias que já tinham sido desenvolvidas. Cada um dos outros sebastiães se relacionou com este, o qual, por sua vez, mantinha uma relação constante com a figura feminina. Isso me levou à construção já de uma história central, a qual girou ao redor desse homem que sustém um casamento de maneira simultânea com 
suas aventuras eróticas com outros homens. $\mathrm{O}$ quadro e a leitura de $\mathrm{O}$ imoralista, assim, alimentaram as particularidades dessa relação entre o protagonista e sua esposa, Marcela ${ }^{6}$, na qual a mulher se mantém em atitude submissa.

Suely Rolnik (2006) diz que "[a]s cartografias vão se desenhando ao mesmo tempo (e indissociavelmente) em que os territórios vão tomando corpo" (p. 46). Eis o que aconteceu com a consolidação da ficção do espetáculo. Como o fazer que vai ao encontro da forma na criação artística, que se define de maneira simultânea com essa formatividade, o território foi começando a ter uma corporeidade que demandou a necessidade de criar essas cartografias, essas rotas que deviam ser seguidas. Foi aí que apareceu a necessidade de criar roteiros que servissem de guia para o advento da forma definitiva como a ficção geral seria apresentada.

Para o princípio de junho de 2013, várias das microficções tinham começado a se desenvolver de maneira independente. Além das mencionadas, três fragmentos que narravam encontros homoeróticos que começavam na rua, na academia e em uma sauna começavam a ter forma. Além disso, já existia um primeiro esboço da relação entre o protagonista e sua esposa. Mas todos esses fragmentos ainda não encontravam ligação. Por isso, no dia 9 de junho, elaborou-se o primeiro dos roteiros.

Como se pode observar no Apêndice A, a partir daquele dia, desenhou-se uma estratégia de roteiros que iam conduzindo à conformação da ficção geral. Na primeira versão, além do mencionado, projetava-se a criação de uma narração inicial que contasse os pormenores da relação do homem com Marcela e como ele se "descobre" homossexual. O final, ainda não muito bem definido, contemplava um retorno ao tema do casamento.

Aquele 9 de junho parecia ter revelado o destino da ficção que estava prestes a se construir. Uma primeira imagem geral do que seria

6 Na obra de André Gide, a personagem feminina tem o nome de Marceline. A escolha pelo nome da esposa do protagonista de Meus caros amigos é uma homenagem ao autor francês e uma "piscada" (pista) para que o espectador possa conhecer o romance. 
o espetáculo unipessoal se projetava e, aparentemente, definiria o que seria visualmente para o espectador. A história já tinha uma estrutura, algumas situações e uns personagens que entravam nelas. Sobre essa base, a montagem continuaria. Mas, três dias depois, o roteiro teve que ser modificado. Essa imagem, que com tanta força tinha definido a ficção, três ensaios depois, já teve que ser repensada. No Apêndice A, pode se seguir essa e as posteriores mudanças que a estrutura do roteiro sofreria. Conservam-se as datas das diferentes versões com o interesse de que possa se observar que, por períodos de diferente duração, os roteiros funcionavam e que as mudanças não tiveram um padrão que explicasse suas aparições. Elas se deviam a circunstâncias dadas pelo desenvolvimento dos ensaios em si.

Esse tipo de desvios se dá constantemente em qualquer processo criativo. Mesmo nos casos em que o artista acredita ter clareza sobre o seu próprio fazer, nada garante que suas ações o dirijam ao resultado que ele almeja, pois só a realização dará conta do que a obra precisará para a consolidação de sua forma. Sobre isso, Pareyson (1993) assinala que só experimentando e tentando o artista poderá saber o que é pertinente.

E só depois de acabado o processo, concluída a obra, terminada a formação, é que ele saberá o que deveria fazer e como deveria fazê-lo, e o sabe justamente quando no fundo, não precisa mais sabê-lo, pois já terminou o que deveria fazer e o executou com pleno sucesso. (p. 69-70, itálico no original)

As afirmações de Pareyson não explicam unicamente as diferentes mudanças que podem se evidenciar em cada versão de roteiro, mas também todo o desenvolvimento do processo criativo. Vale a pena lembrar que a primeira imagem que concretizava esse processo como encenação era a adaptação de $O$ imoralista. Mas, como se pretende demonstrar aqui, o próprio fazer foi modificando essas imagens iniciais e revelando a forma que, depois da estreia do espetáculo, parecia ser a única possível. No final, por exemplo, O imoralista, para fechar o exemplo, acabou sendo mais um material criativo, e não a coluna vertebral do projeto. 
Temas, tópicos, histórias e situações foram entrando e saindo dos roteiros, procedentes de diferentes fontes. Por citar alguns, o tema da doença procede de André Gide, enquanto o da viagem provém da experiência autobiográfica. A aparição desses tópicos foi afinando as particularidades da ficção apresentada e permitiam a interligação entre microficções. Também, ao contrário, permitiam definir o que, afinal, não seria pertinente.

Observando o Apêndice A, o leitor poderá perceber, por exemplo, que se insistiu em uma microficção que acontecia no contexto de uma sauna. Como ambiente que atrai particularmente a comunidade gay, sentia especial interesse em contar uma história que acontecesse nesse espaço, mas o processo foi dando conta de que aquela microficção não conseguia entrar na lógica que estava se desenvolvendo. Finalmente, como se pode observar na versão de roteiro do dia 20 de junho (Apêndice A), tive que desistir dela. A saída da história da sauna teve bastante resistência no começo e rejeitá-la me deu uma sensação de fracasso. Mas o processo já tinha demonstrado que, na tentativa constante, se encontravam as respostas do que devia ou não devia ser feito e que tanto as descobertas felizes quanto os fracassos faziam parte do que daria forma final à obra.

A tentativa tem algo de ordem e desordem ao mesmo tempo, de sorte que a norma que a guia nunca é assim tão evidente que indique de antemão a sua descoberta, e a série dos fracassos não é nunca tão desastrosa que não se converta em alguma sugestão do resultado feliz. (Pareyson, 1993, p. 74)

Os fracassos —assunto que Pareyson (p. 74) relaciona diretamente com a natureza da regra intrínseca da obra de arte-, as renúncias e as rejeições também faziam parte do processo de criação. A elaboração de roteiros foi fundamental para encontrar os meios para tomar decisões e ampliar as possibilidades ficcionais de Meus caros amigos. Finalmente, chegou-se à versão definitiva no dia 17 de agosto (Apêndice A), a qual cartografa a estrutura que deu forma final ao espetáculo unipessoal. 
Definida a estrutura ficcional, Meus caros amigos se apresenta como um exercício confessional do seu protagonista, no qual se expõem as memórias de um homem que sente a necessidade de desvelar uma existência até esse momento escondida. Trata-se de um indivíduo que fala de si mesmo, de seus encontros e desencontros com a experiência erótica, de suas aventuras e de seus erros, de seu desejo de liberação e da educação que o levou a viver sua sexualidade na clandestinidade. Para o espectador, o tom confessional do espetáculo o enfrenta com a narração de uma vida, mas não se trata de uma apresentação biográfica tradicional, já que esse tipo de relatos tende a ser exemplar, é formado por discursos enaltecedores do personagem e tem a intenção de destacar o herói ou o político (Nunes-Ferreira Neto, 2005). Ao contrário, fala das paixões, das experiências cotidianas, dos insucessos, das diferenças e dos interesses do protagonista, o que, no geral, não encontra lugar nas biografias tradicionais, já que elas privilegiam a dimensão pública dos personagens (Nunes-Ferreira Neto, 2005) ${ }^{7}$.

Não é o caso do apresentado em Meus caros amigos. Ao contrário, a ficção proposta mostra uma ideia de vida pública mentirosa, que critica as instituições. Enaltece-se aqui a exposição do íntimo. $\mathrm{O}$ protagonista nunca é tido como exemplo para ninguém. Suas paixões são o mais importante e acaba sendo falado mais de culpa do que de coragem ou de qualquer outra característica heroica.

7 Neste ponto, percebi uma conexão entre os interesses deste processo criativo e os de minha pesquisa de mestrado. No mestrado em Literatura, ocupei-me de um tipo de romance que se sustenta basicamente na premissa de dar voz àqueles que têm sido silenciados pela memória oficial. A pesquisadora venezuelana Luz María Rivas (2004) chama esse tipo de obras de "romance intra-histórico" (novela intrahistórica, em espanhol). Trata-se de um tipo de literatura que privilegia a narração da História (como $\mathrm{H}$ maiúsculo) a partir da perspectiva íntima (daí o radical intra). Naquela época, interessava-me estudar obras que privilegiavam o discurso de mulheres e de exiliados, como indivíduos que permaneciam às margens da sociedade. Agora, neste processo de pesquisa/ criação doutoral, aparecia a necessidade de levar ao palco a perspectiva do homossexual exiliado. Talvez se trate simplesmente de uma necessidade que me persegue como pesquisador artista. 


\section{Apropriação da palavra}

Sempre fui um ator de texto. E, quando falo em texto, não me estou referindo só a essa relação já apresentada do texto dramatúrgico com o ofício da interpretação. Estou falando de que sempre fui um ator que encontrou na palavra falada um meio expressivo fértil. Começo esta parte do capítulo com esse esclarecimento porque acredito que a palavra não é necessariamente a forma expressiva por excelência da cena - estaria desconhecendo uma grande tradição de teatro gestual-, mas, no meu caso, faz parte fundamental dos meus interesses como artista. Não é por acaso que, dentro dos materiais criativos, os literários tenham um lugar tão importante.

Dito isso, falar do surgimento da palavra no espetáculo representa um ponto crucial na medida em que contradiz tudo o que sempre fiz na minha experiência teatral. Reconhecer-me como "ator de texto" é também reconhecer que sempre fiz parte de uma tradição na qual o texto estava em primeiro lugar. No caso do processo de Meus caros amigos, essa relação se inverteu. Como material literário, o qual poderia ser usado inclusive para posteriores encenações, o texto foi o último que se concretou como realidade física.

O roteiro de preocupações já evidenciou que existia desde o começo um interesse narrativo. A palavra foi fundamental para cumprir com esse desejo, já que é a ferramenta fundamental para o desenvolvimento dessa preocupação. Além disso, a consolidação da ficção definiu o fazer do protagonista do espetáculo: ele estava na frente de uma reunião convocada por ele mesmo para falar da sua vida íntima, para confessar o inconfessável. Nesse sentido, falar se constituiu uma ação fundamental da cena e é a partir dela que o homem consegue tirar do seu interior aquilo que o oprime.

A palavra é, assim, ação verbal ${ }^{8}$, e não simplesmente a utilização de mais um recurso cênico. Do ponto de vista da ficção, tratava-se de

8 Um dos primeiros a falar de ação verbal é Constantin Stanislávski. Para o diretor russo, "[é] a partir da construção das imagens interiores que o ator pode fazer com que a utilização da palavra se transforme em ação verbal" (citado por Bonfitto, 2009, p. 117, itálico no original). Assim, Stanislávski separa a ação verbal do que seria a ação física, considerando-a outro tipo de ação, mas 
pôr em palavras uma série de sentimentos que ocupa o mundo interior do protagonista, o que, finalmente, coincidia também com o interesse do ator-autor. Já que a motivação fundamental da criação do espetáculo era apresentar o próprio dizer, a palavra era a ponte entre o que pretendia tanto o indivíduo da ficção quanto o artista que a apresentava.

É por isso que se fala aqui de apropriação da palavra. De alguma maneira, era tomar o controle do discurso verbal, era reconhecer que, no caso do ator, as palavras não tinham que ser escritas ou proferidas por outros, era continuar construindo esse espaço poético no qual a palavra também era apropriação particular das coisas do mundo, construção e exposição particular de um imaginário.

O primeiro procedimento para conseguir essa apropriação da palavra era o uso da primeira pessoa do singular, já mencionado de diferentes maneiras nos capítulos anteriores. Como procedimento operacional, tratava-se de fortalecer o eu no discurso, de falar por conta própria, o que, de novo, aplica-se tanto no campo ficcional quanto no das intenções do artista. Embora esse tipo de abordagem esteja presente em muitas formas de espetáculo, à exceção do unipessoal, e que aparentemente isso não demandasse nenhum tipo de dificuldade, na realidade, constituía um desafio criativo no qual se precisava quebrar um pudor que já me perseguia algum tempo: o de considerar que era pedantismo expor minha própria visão do mundo.

Francisco Ernesto Puertas Moya fala desse assunto quando analisa o uso gramatical no discurso autobiográfico. No contexto desta pesquisa/criação, as asseverações do semiótico são relevantes na medida em que reconhecem a mudança paradigmática que implica esse tipo de discurso, o qual, habitualmente, considera-se politicamente incorreto.

Existe um tipo de pudor na hora de utilizar a primeira pessoa do singular em âmbitos públicos, fora do uso familiar e coloquial ao qual esse uso fica restringido. Tem que se ter muita autoridade para

leva em conta que o ator está em capacidade de experimentar diferentes possibilidades de sobreposição entre elas. 
se expressar com propriedade em uma forma tão crua, tão direta, tão exposta à crítica e à reprovação social. Eu acredito, eu penso, eu acho, eu acuso, etc., são formas pouco aconselháveis para quem não quiser quebrar as formas de prudência e modéstia que dita a vida pública. (Puertas, 2004, p. 50, tradução minha)

Dessa forma, cada microficção acabou se convertendo em uma pequena narração na qual me permitia expor minha própria visão de mundo. A palavra falada, nessa perspectiva, tinha duas funções fundamentais: a primeira era a apresentação da ficção construída; a segunda a exposição do meu pensamento com relação ao tema da homossexualidade. Ambas as funções faziam parte do meu imaginário e, portanto, faziam uso dos diferentes materiais criativos.

Em termos da construção ficcional, a palavra me permitia contar a história de um homem que se casa por convenção, fica doente pouco tempo depois do casamento, no meio da doença se "descobre" homossexual, viaja ao Brasil com o interesse de encontrar "novos ares" e novas motivações e, nesse novo país, abre-se à possibilidade de viver seus impulsos eróticos. O uso da palavra também me deu a liberdade de criar personagens, nomeá-las e envolvê-las em situações que delatam seus desejos e frustrações.

Em relação àquilo que queria apresentar desde o começo, a palavra me deu a oportunidade de expor meus argumentos quanto ao amor homossexual, à dupla moral que existe ao redor da homossexualidade, ao sentimento de culpa que a cultura ocidental tende a impor aos homossexuais, à minha rejeição aos costumes da sociedade cristã, à minha perspectiva sobre o conceito de pecado, sobre a ideia de beleza, enfim, sobre uma série de temas que o espetáculo foi revelando como necessários e que deram conta dos sentidos que, na hora de começar com o roteiro de preocupações, não estavam tão claros para mim.

Essa exposição de assuntos foi possível justamente porque, desde que a palavra começou a ganhar espaço na encenação, a premissa de favorecer o uso da primeira pessoa me colocou como agente emissor do conteúdo. Isso fez com que os materiais criativos também sofressem novas formas de apropriação. Os quadros deixaram de representar o santo para começar a representar os amantes do protagonista, esses 
“caros amigos" que passaram pela sua vida. Igualmente, em alguns momentos, por exemplo, as ideias apresentadas por Gide em seu Corydon transformaram as minhas, e o discurso final se nutriu de suas palavras. $\mathrm{O}$ mesmo processo acabou acontecendo com alguma frase de Gaston Bachelard, teórico tão apreciado nos pressupostos desta pesquisa, que acabou encontrando seu lugar verbal no espetáculo.

Tudo aquilo aconteceu no meio de um processo de criação autônoma no qual o ator preparava um espetáculo para ser apresentado em um país que não é o seu e em uma língua que também não é a sua. Além do temor que produzia essa escolha por favorecer o eu no discurso verbal, existia um segundo que me outorgava ainda mais "autoridade": o fato de ser estrangeiro, de criar um espetáculo unipessoal em uma língua que nem sequer era a minha, uma língua que não dominava. Chegar à palavra adequada era, sem dúvida, ainda mais difícil do que se tivesse desenvolvido o processo em espanhol. Mas era uma circunstância que não queria esquivar. Desde o início, fui consciente de que falaria para um público que me veria como estrangeiro e, paradoxalmente, foi como forasteiro que encontrei meu dizer.

A palavra para o estrangeiro não se reduz à sua carga semântica. De fato, ninguém é tão ciente da materialidade da palavra em si —sua sonoridade-como aquele que tem que se expressar em uma língua que não é a sua. Uma das dificuldades que experimentei desde que comecei meus estudos de português foi enfrentar uma fonética mais complexa do que a espanhola. Isso fazia com que pensasse que atuar na língua portuguesa seria o maior desafio do espetáculo. Sobretudo porque é habitual escutar, a partir da experiência de outros atores, o difícil que é atuar em outro idioma. Além disso, escutam-se também argumentações que falam dessa circunstância quase em termos de impossibilidade. Os atores, os encenadores e os cineastas Patrice Chéreau e Luc Bondy (citado por Banu, 2011), por exemplo, afirmaram que "[s]ó se pode ser um grande ator atuando na sua língua materna” (p. 399-400) e que “[s]ó se pode atuar ou encenar na língua na qual se sonha" (Bondy citado por Banu, 2011, p. 400).

Superando o medo que produz esse tipo de afirmações, a experiência da criação de Meus caros amigos deu outra perspectiva a esse assunto. O desafio permitiu que a palavra fosse algo mais além do que ela mesma 
nomeia. Era uma espécie de música estranha, um conjunto de sons que não só falavam de algo, mas também demandavam um esforço diferente em termos de composição.

Matteo Bonfitto (2009), falando do uso da palavra no teatro de Meierhold, assinala:

[p]artindo da materialidade das ações e palavras e não dos aspectos semânticos presentes no texto, o ator é forçado a colocar-se diante de um objeto "não conhecido a priori". Somente a partir de sua execução poderá ele "descobrir" as suas possibilidades de significação. (p. 120)

Essa argumentação define claramente o que acontecia com o uso da palavra neste processo criativo e dava-lhe, de novo, esse caráter de fazer cartográfico, já que não existiam regras para abordá-la que não fossem dadas pela execução em si.

A língua, assim, era um objeto estranho que aumentava as possibilidades criativas e dava à palavra uma materialidade que permitia essa ideia de formatividade. Era uma espécie de material maleável, cujas particularidades eram as que ditavam as regras. A palavra acabou dando ritmo ao espetáculo, mas era um ritmo produto de uma exploração na qual nada estava dado de fato. Passei a pensar, desse modo, que a língua não era um obstáculo, mas uma oportunidade criativa a mais, na qual eu tinha a chance de lhe dar novas nuanças. "O ator estrangeiro abre e enriquece o espectro sonoro da língua de acolhimento. Ela é perturbada, deslocada [...]" (Banu, 2011, p. 391).

Os alcances conseguidos com o uso da palavra se registram no Apêndice $\mathrm{B}$, correspondente ao texto dramatúrgico que encontrou forma depois da estreia do espetáculo. As falas que se encontram nesse texto correspondem às que se escutam no espetáculo unipessoal, mas as rubricas são produto de uma leitura posterior e não correspondem nem às ações apresentadas nem aos aspectos visuais da obra. Trata-se de um texto dramatúrgico que aproveita o discurso verbal desenvolvido no processo criativo, mas que funciona como objeto independente, já que espetáculo e texto se reconhecem, na lógica desta pesquisa, como produtos criativos autônomos e, da mesma forma que se pretende 
distanciamento daquela tradição que considera a encenação como transposição do texto literário, não pretende considerar o texto aqui produzido como evidência material do espetáculo unipessoal anterior a ele. É por conta disso que, na posterior publicação do texto dramatúrgico no número 23 da revista Repertório (González, 2014a), não se faz referência à encenação e se publica com o objetivo de ser divulgado entre a comunidade teatral como qualquer texto dramatúrgico que possa interessar a futuras encenações.

Finalmente, o que aconteceu com esse exercício de escrita foi o anunciado acima: o texto foi o último. A partir do desenvolvido no ato criativo, que acabou no palco, foi possível a aparição de uma dramaturgia escrita posteriormente. Isso porque, nesta pesquisa, o texto escrito é consequência, e não ponto de partida, relação muito diferente da minha experiência profissional anterior, na qual, como assinala Jorge Eines (1997b), “[o] acontecimento cênico, o qual não tem sua origem na cena mesma, começou sendo uma palavra circulando pela imaginação de um indivíduo [e] desenvolveu-se na dolorosa confrontação com um papel em branco" (p. 19).

A escrita no processo de Meus caros amigos foi, inicialmente, um exercício de registro e de memória da própria experiência criativa. Nesse sentido, ocupou um lugar muito próximo ao da escrita na pesquisa cartográfica, para a qual é uma prática preciosa (Passos, Kastrup e Escóssia, 2012). As anotações na cartografia “[...] colaboram na produção de dados de uma pesquisa e têm a função de transformar observações e frases captadas na experiência de campo em conhecimento e modos de fazer” (Passos, Kastrup e Escóssia, 2012, p. 70).

$\mathrm{Na}$ experiência deste processo criativo, anotar foi uma necessidade constante, a qual acabou dando forma à narração apresentada no palco. Cada narração produto da construção de uma microficção ia encontrando as palavras na sala de ensaio a partir da oralidade. Em seguida, o discurso passava a ser escrito, e o texto sofria as transformações que a sala de ensaio ditava. Nesse sentido, a primeira função do exercício de escrita era a captação dessa oralidade conseguida nos ensaios, mas a segunda era a transformação e a adequação desses dados ao interesse comunicativo das narrações registradas. A fase de escrita permitia resolver dúvidas, realizar correções idiomáticas, encontrar relações 
de sentido e cartografar de outra maneira o que se estava realizando também com a estratégia dos roteiros.

Como se pode observar no Apêndice $\mathrm{B}$, as falas constituem o material por excelência do texto que se produziu e apresentam-se de maneira fragmentada. Cada uma das partes que conformam o texto dramatúrgico corresponde a um momento da criação, o que permitiu organizar também a ficção em termos de discurso. Finalmente, o registro escrito das narrações apresentadas no espetáculo dá conta dessa ideia geral de que cartografar é acompanhar processos.

Já se tratou antes do tema da apropriação da palavra falada como discurso ficcional e artístico e como materialidade da cena. No entanto, para encerrar esta parte do capítulo, teremos que falar de dois tipos de apropriação do que seria a palavra escrita. O primeiro é o que temos abordado até agora: a palavra escrita como dramaturgia, a qual não evidencia um exercício a priori, mas se apresenta como registro e acompanhamento do processo criativo. $\mathrm{O}$ segundo tipo de apropriação da palavra escrita estaria mais relacionado com o acompanhamento do processo como pesquisa.

Nessa categoria, a redação e a publicação do blog $\mathrm{O}$ ator em solidão (González, 2013b) aparece como outro meio pelo qual este processo de pesquisa/criação assume caráter cartográfico. Trata-se de um blog que acompanha o processo de criação do espetáculo desde janeiro de 2013 e apresenta tanto momentos específicos do processo quanto reflexões geradas no seu interior.

Ao considerar que "[a] política da escrita deve incluir as contradições, os conflitos, os enigmas e os problemas que restam em aberto" (Passos, Kastrup e Escóssia, 2012, p. 72), o blog cumpre essa função e apresenta-se com um espaço de acesso aberto no qual se compartilham dúvidas, impressões e cogitações que se desprendem do processo de pesquisa e de criação. De alguma maneira, é um outro espaço de registro e foi fundamental para o desenvolvimento de reflexões que encontram neste livro um espaço mais amplo para seu aprofundamento.

Seja falada, seja escrita, a apropriação da palavra foi fundamental na consolidação do processo de criação de Meus caros amigos. Por um lado, a palavra permitiu o desenvolvimento da ficção e a apresentação 
de uma forma de ver o mundo que como artista precisava apresentar. Por outro, é acompanhamento do processo, tanto criativo quanto de pesquisa, além de registro de uma experiência.

\section{Autonomia ao lidar com os elementos da cena}

A consolidação da ficção e a apropriação da palavra eram alguns dos interesses que mais eu ansiava resolver, mas eram só uma parte do acontecimento cênico que eu enfrentava. Como ator emancipado, tinha que me preocupar por assuntos que não tinham sido minha responsabilidade em experiências anteriores, o que demandava novos desafios. Mas de que exatamente devia me ocupar? Em seu livro Drama em cena, Raymond Williams (2010) o resume da seguinte maneira:

[o] teatro é comumente feito de quatro elementos: fala (em seu sentido mais geral, englobando, por vezes, o canto e o recitativo, bem como o diálogo e a conversação); movimento (abarcando gesto, dança, representação física e evento encenado); espaço cênico (englobando cena, cenário, figurino, e efeitos de luz); e som (diferente do uso da voz humana - música, "efeitos sonoros", por exemplo). (p. 218)

Teria que me ocupar também, então, disso que Williams chama de movimento, espaço cênico e som. O segundo desses itens tinha começado a se resolver bem cedo no processo criativo. Quando se definiu o fato de estar construindo meu espaço poético, encontrei algumas possibilidades espaciais que começaram a ter forma na experimentação pública feita em março de 2013 (Figura 10). Imagens e textos se encontravam pendurados e criavam um espaço evocador mais próximo de uma atmosfera onírica do que de um espaço realista. Um processo de depuração desse ambiente inicial levou a que só se mantivessem penduradas algumas imagens de são Sebastião. $\mathrm{Na}$ temporada de estreia, contava-se com nove imagens penduradas no fundo do palco, em representação do protagonista, de seus jovens amantes e de sua esposa. 
Os deslocamentos que se produziam no espetáculo estavam dados pelas relações que existiam entre as histórias narradas e as imagens determinadas para a representação dos sujeitos dessas narrações, o que levou à necessidade de transformar a disposição e a quantidade das imagens para a segunda temporada. $\mathrm{Na}$ versão final, só ficaram sete quadros, e as imagens foram distribuídas pelo palco a diferentes alturas e localizações, levando algumas até o proscênio.

O público que assiste ao espetáculo observa um cenário no qual as imagens ocupam uma importância visual predeterminada, já que é finalmente esse espaço o que dá o nome ao espetáculo. Meus caros amigos é um título que surgiu, na ficção, dessa apresentação do protagonista de sua experiência íntima, conformada por uma série de jovens homossexuais. Eles representam seu ser erótico e sua ideia de beleza e de amor. Por isso, o espectador assiste à exposição deles no palco. As pinturas também ganharam tamanho na versão final da encenação, o que favorece essa intenção de exposição que existe na visualidade do espetáculo. Finalmente, trata-se de um convite a ver esses "caros amigos".

É por isso que o espaço cênico é uma representação mais do princípio de multiplicidade que define os procedimentos deste processo criativo. Cada um dos são sebastiães representa uma microficção, um momento diferente da existência do protagonista, e o espectador se depara como isso desde o começo. Assim, o título dado por esse espaço resume a ideia da multiplicidade do indivíduo. Trata-se da apresentação clara de um eu (meus), mas a partir de uma experiência plural, multíplice e significativa (caros amigos).

Outros dois elementos cenográficos aparecem no espetáculo. No fundo, uma bacia de alumínio cheia de água que abre o espetáculo com um banho que o protagonista toma diante dos espectadores. No proscênio, um prato de cerâmica no qual serão queimados documentos e fotografias no final do espetáculo. Assim, refere-se a uma obra que começa com água e termina com fogo, em uma intenção clara de fazer da ação cênica um ato de expiação e catarse para o protagonista (falando em termos da ficção) e de jogo de convenções para o criador do espetáculo.

Definido assim o cenário, a luz acompanha esse percurso através desse espaço evocador, iluminando o andar do ator por essas experiências íntimas. Nesse sentido, a luz tende a fechar os espaços das 
microficções para fortalecer essa ideia de intimidade que se pretende criar a partir das narrações. Pouca cor define a iluminação do espetáculo, tentando que a atmosfera geral se nutra mais das cores dos quadros. Só no começo (na ação do banho) e no meio do espetáculo (para ressaltar uma sequência de movimentos inspirada nas posturas de todos os sebastiães que passaram pelo processo), a luz entra para dar cor à atmosfera.

O figurino também não contribui com muita cor ao cenário. O protagonista usa uma calça preta e um roupão vermelho escuro. Começa nu e vestir-se é uma ação que corresponde à preparação para o que pretende desenvolver. Em outro momento, fará o contrário para revelar uma nova história ou para se apresentar ante a plateia de maneira mais crua.

Poucos objetos fazem parte desse espetáculo unipessoal. Algumas fotografias, um bilhete e uma pasta com documentos legais completam o quadro visual da peça. Assim, cenário, figurino, luz e objetos conformam isso que Williams chama de espaço cênico e que complementam a construção do espetáculo.

O quarto elemento apresentado por Williams é o som. A trilha sonora do espetáculo está conformada por três peças musicais que sempre me causaram comoção: Erbarme Dich, Sein Gott, ária que faz parte de A paixão segundo são Mateus, de Johann Sebastian Bach; a Havaneira, ária da ópera Carmen, de Georges Bizet, e uma versão musical do poema de Federico García Lorca Gacela del amor que no se deja ver, cantado por Carlos Cano. A primeira delas foi usada várias vezes na fase de exercício para realizar atividades de concentração. Sua escolha inicial foi arbitrária, já que estava aí só pelo gosto que ela me produz. Mas, no final, ela se tornou o guia para a definição da trilha.

Sem ter planejado, o Erbarme Dich acabou sendo parte da construção do meu espaço poético e, da mesma maneira que fez parte da preparação para o encontro e a definição de procedimentos criativos, serviu para dar forma à preparação do protagonista do espetáculo. Foi assim que a peça de Bach terminou acompanhando o banho com o qual o homem se preparara para receber seus amigos. 
A letra da peça musical também tem uma relação direta com o momento que o protagonista do espetáculo atravessa. Ele convoca seus amigos precisamente pela necessidade de expiar a culpa. Assim, o que se diz nos mais de sete minutos que dura a ária se contrasta com a imagem de um homem nu que se prepara para enfrentar o juízo da plateia. Em português, a letra diz o seguinte:

Tem piedade, meu Deus, por causa das minhas lágrimas!

Olha aqui, coração e olhos chorar amargamente diante de você.

Tem piedade, meu Deus. (tradução extraída da internet)

Interessou-me particularmente começar o espetáculo com uma peça de música sacra porque muito do que se vê em Meus caros amigos é uma dessacralização de discursos. No espetáculo, os santos perdem seu caráter religioso para se converter em referências homoeróticas. Com isso, quis criar o contraste entre uma música que está pedindo o auxílio de Deus e o homem que toma banho escutando essa música, mas ao ritmo de uns movimentos que sugerem um conteúdo mais pagão.

Como assinalei acima, a ária de Bach tornou-se o guia para a introdução das demais peças musicais. As três coincidem em tratar um tema em comum: o amor. Mas esse tema é tratado de maneira bem diferente. Enquanto Bach fala do amor a Deus, a Havaneira da ópera Carmen se refere a um tipo de amor menos transcendente e obviamente mais mundano. "O amor é um pássaro rebelde"10 é uma das frases mais significativas do cantado por Carmen. Ela resume uma maneira de entender o amor que vai de um lugar para outro, que não pode ser domado, que faz ninho aqui hoje, mas amanhã o abandona e começa uma nova viagem.

9 Erbarme dich, mein Gott, / um meiner Zähren willen! / Schane hier., Herz und Aude / weint vor dir bitterlich. / Erbarme dich, mein Gott (disponível em: <http://letras.mus.br/johann-sebastian-bach/1561978/traducao.html> Acesso: 24 jun. 2014).

10 "L'amour est un oiseau rebelle" diz o original em francês. 
A Havaneira deu lugar à aparição de uma sequência de movimentos inspirada nas poses de são sebastiães que passaram por este processo criativo. A ária se escuta no espetáculo depois de ter contado todas as experiências homoeróticas do protagonista e combina várias das diversas posições de dor, êxtase e devoção que caracterizam o santo. $\mathrm{O}$ contraste aqui funciona ao contrário na cena do banho. Enquanto as imagens corporais fazem referência ao sacro, é a música a que revela o conteúdo pagão.

A terceira música que completa a trilha sonora é a de Carlos Cano, que canta o poema de García Lorca. Trata-se de um poema que faz parte da coletânea Divã do Tamarit. Com o título de "Gazel do amor que não se deixa ver" ${ }^{11}$, esse poema se inscreve no que o crítico Epicteto Díaz (1990) chama de "amor escuro" (p. 36), referindo-se ao amor homossexual, o qual, por imposição social, é preciso ocultar. A música inspirada no poema lorquiano encerra a peça e contextualiza uma ação de incineração de documentos e fotografias que guardam relação com o casamento heterossexual.

Segundo Díaz (1990), o amor escuro que apresenta García Lorca em seus sonetos e em alguns dos poemas do Divã do Tamarit expressa um tipo de amor que se movimenta entre o prazer e a dor, o que o faz ainda mais inominável. No poema que em questão, por exemplo, a presença do corpo amado é tão dolorosa que faz com que se produza o esquecimento de sua identidade (Díaz, 1990). Assim, pode se perceber nos versos finais:

\author{
Somente por ouvir \\ o sino da Vela \\ abraçava-me em teu corpo \\ sem saber de quem era ${ }^{12}$. (García, 1989, p. 66, tradução minha)
}

11 Note-se a semelhança existente entre o título do poema "O amor que não se deixa ver" e a famosa expressão "o amor que não ousa dizer seu nome" que, desde Platão, se usa para nomear a relação entre um homem mais velho e um mais jovem.

12 Solamente por oír / la campana de la Vela / me abrasaba en tu cuerpo / sin saber de quién era. 
A trilha sonora do espetáculo está, pois, composta por três músicas que fazem referência a três tipos de amor. Portanto, cada uma delas convidava a desenvolver três tipos diferentes de ações. As músicas também fazem parte do meu acervo e entraram na encenação a partir de necessidades que foram dadas pelo processo em si. Mas, embora façam parte do meu acervo, nunca foram consideradas materiais de trabalho, e sim matrizes geradoras da ação.

Por matrizes geradoras entendemos qualquer referência utilizada para a confecção das ações físicas. Podemos ter como exemplo textos escritos, dramáticos ou não, referências visuais, sonoras, experiências pessoais ou construídas... Os elementos de confecção, assim como os procedimentos de confecção estão ligados aos aspectos que caracterizam a ação física em cada caso. (Bonfitto, 2009 , p. 96, itálico no original)

Nesse ponto, me interessa fazer referência ao último dos elementos mencionados por Williams (2010) que faltava por considerar: movimento. Com movimento, Williams se refere ao trabalho da ação física em suas diversas manifestações. No caso de Meus caros amigos, a ação é o produto de uma série de interações com os diferentes elementos de trabalho: figurino, objetos, cenário e música.

A ação física na encenação desse espetáculo unipessoal aparece de múltiplas formas: é ação cotidiana quando se interage com os objetos, dança quando o faz com a música e gesto quando acompanha o discurso verbal. Como assinala Bonfitto (2009), o ator “[...] deve fazer dos elementos com os quais se relaciona uma 'fonte de estímulos' que pode levá-lo à descoberta de diferentes possibilidades expressivas” (p. 120).É precisamente isso o que aconteceu neste processo criativo. As músicas, por exemplo, foram fonte fundamental de estímulo para a criação de cenas que ganharam força expressiva dentro do espetáculo.

O banho inicial ao ritmo de Bach, a sequência que acompanha a Havaneira e o ritual de despedida do protagonista ao queimar as fotografias enquanto escuta o poema de Lorca cantado por Cano mostram como as músicas estimularam momentos cruciais no desenvolvimento do espetáculo. Elas — suas letras, pelo menos— não estão relacionadas 
diretamente com o dizer do espetáculo, como fazem as referências pictóricas e literárias, mas motivam o surgimento e a concepção da ação cênica. Nesse sentido, estabelece-se aqui uma diferença fundamental entre o que Bonfitto chama de matrizes geradoras e o conceito de material que esta pesquisa defende. Enquanto os materiais estimulam o desenvolvimento do dizer do artista, as matrizes geradoras estimulam a criação da ação física ${ }^{13}$.

Assim, este processo de criação encontra no cenário, no figurino, nos objetos e na trilha sonora elementos que estimulam a aparição da ação. Nesse sentido, o processo de criação favoreceu uma aproximação com essas funções criativas que, na experiência profissional passada, eram tarefa do encenador.

Como ator emancipado, assumir a responsabilidade criativa no design do cenário e do figurino, por exemplo, mudou uma maneira de adotar a criação da ação cênica. No contexto do ofício, esses elementos sempre apareciam por imposição do encenador, e o meu trabalho como ator consistia em encontrar os meios para adaptar essas realidades à criação da ação física. No caso deste processo criativo, as escolhas estéticas apareciam em simultaneidade com ela, o que fez com que, por exemplo, a movimento cênico fosse um trabalho elaborado enquanto o cenário estava sendo preparado. Algo similar aconteceu com o figurino e os objetos que se manipulavam em cena. Entre eles e a ação física, deu-se uma relação simbiótica, a qual fez com que não existissem separações entre os diferentes momentos e os aspectos na hora de criar. Não houve um tempo do cenário, ou do figurino, ou da ação física; houve um tempo no qual a obra, nos seus diversos elementos constitutivos, como um todo multíplice e singular, ao mesmo tempo, encontrou a forma.

Essa simultaneidade na criação dos diferentes elementos da encenação não só explica o surgimento da forma final que obteve o espetáculo unipessoal, mas também definiu um último aspecto que se

13 Essa afirmação pode parecer radical e até desnecessária para quem considera que é a partir e unicamente da ação física que o ator compõe. No universo do ofício de interpretação, realmente acredito que a distinção pode ser pouco importante; mas, no âmbito da afirmação do dizer pessoal do ator-criador, parece-me uma diferenciação relevante. 
deve considerar neste capítulo. Na primeira parte, fala-se de como a proposta inicial contemplava várias etapas, nas quais a primeira era a da escrita de um texto dramatúrgico que apresentasse uma ficção que pudesse ser representada no palco. Como pôde ser observado, esse texto apareceu no final, e a palavra deixou de ser o preâmbulo da encenação. Isso aconteceu porque em algum momento fui ciente de que o que procurava não precisava da separação entre um euartista-dramaturgo e um eu-artista-ator. Com o desenvolvimento da ação cênica, aconteceu algo similar, e é esse o último aspecto do qual se falará a seguir.

A segunda etapa daquela ideia inicial também separava a concepção da sonoplastia, do cenário e do figurino, e planejava uma terceira fase de improvisações filmadas, seguida de um processo de observação e escolha dos materiais que dariam forma à encenação a partir dessas gravações. Nas últimas, o que propunha era uma separação, similar à relacionada com o texto, entre um eu-artista-ator e um eu-artistaencenador. O leitor perceberá que também essa foi uma ideia descartada.

Se alguma certeza apareceu no meio desse encontro às escuras que foi este processo criativo foi que a emancipação necessária para assumir um projeto intitulado $\mathrm{O}$ ator em solidão, em vez de separar (verbo associado à ideia de isolamento), o que teria que fazer era integrar ainda mais um processo cuja "natureza" — refiro-me ao que já conhecia— se fundamentava na separação e na especialização de funções.

Descartar a filmagem como estratégia foi uma decisão que apareceu quase desde o começo do processo. Descobri que estava fundamentada nessa ideia ortodoxa de que o ator tem que ser observado e supervisionado o tempo todo, nessa concepção desenvolvida nos pressupostos de que só se pode ser bom ator da mão de um bom diretor. Claro, isso fez com que fosse necessário renunciar alguns aspectos que - realmente acredito- se desenvolvem melhor quando se tem um olhar externo. Mas, como diz a atriz Denise Stoklos (2012), eu estava "perigosamente achando" que era capaz de tudo.

Foi a última das barreiras que superei. Se queria me aproximar do que fazem outros artistas, como pintores, escultores ou poetas, devia começar por assumir a autonomia no meu trabalho artístico. Mas, como muitos outros dos obstáculos que enfrentei, precisei de alguém 
que me desse o último impulso. Foi a professora, artista e pesquisadora Sonia Rangel que contribui com as palavras que precisava escutar. No seu texto Olho desarmado, a brasileira (2009) assinala:

[a] cada criador corresponde uma demanda interna, e como consequência, a cada criador, e a cada processo criativo, correspondem "métodos" diferenciados. Considero que o artista é um pesquisador nato, mas no âmbito acadêmico, além da capacidade de expressar a obra, o artista precisa sentir-se estimulado a discorrer sobre seus próprios "métodos" e a "experimentar" seu pensamento como criação. (p. 99-100)

Além da reflexão que a pesquisadora apresenta para falar da criação artística no campo da academia, reconhece-se, nessas palavras, a diferenciação de métodos na hora do processo criativo e de suas demandas internas. Eu estava em um processo que convidava à aparição de uma forma de criação autônoma que não tinha experimentado antes, mas essa liberdade que me autorizava a ser quem decidisse sobre o que eu mesmo produzia me causava ainda temor. No seu texto, a professora Rangel descreve seu próprio trajeto criativo em termos de se debruçar. Essa ideia me permitiu entender também o meu.

Este debruçar-se da minha parte é sempre acompanhado de dois sujeitos: "o que faz" e "o que olha". O primeiro conduz e realiza o reencontro com a criação. $\mathrm{O}$ segundo revisita as sensações do ter ou não sentido, do localizado e do deslocado e sempre indaga: que destino dar a essas novas "criaturas"? Sentido e destino vão se confundindo neste fluxo, até que surpreendo uma nova leitura possível deste universo e ele passa a ser constelado como único. (Rangel, 2009, p. 104)

Foi assim que entendi que podia coabitar essas duas entidades no meu fazer e que isso que Sonia Rangel colocava na imagem dos dois sujeitos que ocupam seu ser criador era muito próximo do fazer que Pareyson atribui à capacidade de formar do artista. Tratava-se de atuar sem regras, mas com a intuição disposta para selecionar aquilo que era bom 
para a construção da forma do meu espetáculo e descartar aquilo que não servia. Entendi que, como ator, sempre fui ciente daquele que faz, mas não conhecia aquele que olha.

No ofício da interpretação, o ator é o agente da ação, mas é o encenador que olha e revisita esse fazer para lhe dar forma. Uma vez mais, tratava-se só de manter essa intenção integradora. Não era necessário me separar entre o que faz e o que olha. Todo o contrário: o que tinha que fazer era integrar esses dois em um só.

A simultaneidade entre os elementos compositivos da encenação se deu da mesma maneira que a das funções que permitem que eles encontrem a forma. A execução e a seleção atuaram juntas neste processo criativo fazendo com que essa ideia de autonomia criativa guiasse a construção da forma. $\mathrm{O}$ encontro às escuras, assim, deu à luz o espetáculo unipessoal Meus caros amigos. 
